\title{
38. GEOCHEMISTRY AND PETROGRAPHY OF ORGANIC MATTER IN SEDIMENTS FROM HOLE 530A, ANGOLA BASIN, AND HOLE 532, WALVIS RIDGE, DEEP SEA DRILLING PROJECT ${ }^{1}$
}

\author{
Jürgen Rullkötter, Prasanta K. Mukhopadhyay, and Dietrich H. Welte, Institute of Petroleum and Organic \\ Geochemistry (ICH-5), Kernforschungsanlage Jülich GmbH, D-5170 Jülich 1, Federal Republic of Germany
}

\begin{abstract}
Seventeen sediment samples of Albian-Cenomanian to early Pliocene age from DSDP Hole 530A in the Angola Basin and six sediment samples of early Pliocene to late Pleistocene age from the Walvis Ridge were investigated by organic geochemical methods, including organic carbon determination, Rock-Eval pyrolysis, gas chromatography and combined gas chromatography/mass spectrometry of extractable hydrocarbons, and kerogen microscopy. The organic matter in all samples is strongly influenced by a terrigenous component from the nearby continent. The amount of marine organic matter present usually increases with the total organic carbon content, which reaches an extreme value of more than $10 \%$ in a Cenomanian black shale from Hole 530A. At Site 530 the extent of preservation of organic matter in the deep sea sediments is related to mass transport down the continental slope, whereas the high organic carbon contents in the sediments from Site 532 reflect both high bioproductivity in the Benguela upwelling regime and considerable supply of terrigenous organic matter. The maturation level of the organic matter is low in all samples.
\end{abstract}

\section{INTRODUCTION}

Leg 75 of the Deep Sea Drilling Project (DSDP) was devoted to investigating the paleoenvironmental conditions prevailing in the South Atlantic ocean which have led to the accumulation of sediments rich in organic matter. One of the major objectives was to determine whether deposition occurred at the bottom of an isolated, anoxic basin or within a mid-depth oxygen-minimum zone. Previous deep sea drilling in the eastern South Atlantic during DSDP Leg 40 indicated the presence of numerous organic-matter-rich sediment sequences (Bolli, Ryan et al., 1978 a,b). Cretaceous black shales were found in the Aptian-early Albian, in the late Albian, and in the Turonian-Santonian at DSDP Site 364 in the northern part of the Angola Basin and were interpreted as anoxic basin deposits (Bolli, Ryan et al., 1978b), whereas organic-matter-rich post-late Miocene sediments encountered in the Walvis Ridge area were suggested to be the result of the Benguela upwelling (Bolli, Ryan et al., 1978a).

During DSDP Leg 75, Hole 530A was drilled into the abyssal floor of the southeastern corner of the Angola Basin. The whole sediment sequence recovered was dominated by turbidites derived from the southwest African continental margin (Albian to Miocene) or from the Walvis Ridge (late Miocene to Pleistocene). Black shale layers in the Albian to Coniacian section were interbedded with red and green organic-matter-poor claystones. ${ }^{2}$

Hydraulic piston cores from DSDP Hole 532, close to Site 362 on the Frio Ridge segment of the eastern part of the Walvis Ridge, represent an organic-matter-rich sequence of predominantly pelagic deposits with variable

\footnotetext{
${ }^{1}$ Hay, W. W., Sibuet, J.-C., et al., Init. Repts. DSDP, 75: Washington (U.S. Govt. Printing Office).

${ }^{2}$ Revisions of stratigraphic ages are given in Steinmetz et al., this volume.
}

amounts of terrigenous clay. The organic matter in these late Miocene to Pleistocene sediments is supposed to be influenced by the Benguela upwelling system which started in the Miocene (see site summary, this volume).

Seventeen sediment samples from DSDP Hole 530A and six samples from Hole 532 were studied using organic geochemical and organic petrographic methods. Preliminary results concerning the amount, type, and composition of the organic matter are discussed in terms of its origin, depositional environment, and diagenetic alteration.

\section{METHOD}

For a detailed description of experimental procedures, including total organic carbon determination, Rock-Eval pyrolysis, solvent extraction, liquid chromatography, gas chromatography, computerized gas chromatography/mass spectrometry, and kerogen microscopy, we refer the reader to earlier reports (Mukhopadhyay et al., in press; Rullkötter et al., 1981).

\section{RESULTS: HOLE 530A, ANGOLA BASIN}

Although the seventeen core samples from Hole 530A represent most of the lithologic units, the investigation was concentrated mainly on lithologic Unit 8 (nine samples), which comprises the interbedded black-shale sequence of Albian-Cenomanian to Coniacian age. The organic carbon contents are moderate in the Miocene and younger sections $(0.4-1.0 \%)$, very low in the upper Coniacian to Oligocene $(<0.1 \%)$, and highly variable in Unit 8 (Table 1). Samples 530A-93-5, 135-145 cm and 530A-99-5, 0-10 cm contained thin black-shale layers, but these samples were processed without prior separation of the layers. Their organic carbon contents, thus, represent average values of different lithologies. In contrast to this, Sample 530A-97-3, 105-115 cm showed a clear boundary in the middle between a black shale in the top half and a green claystone. This sample was split, and subsamples of intervals $105-110 \mathrm{~cm}$ and $110-115 \mathrm{~cm}$, 
respectively, were analyzed separately. Organic carbon values of these subsamples show an extreme difference (i.e., $10.6 \% \mathrm{C}_{\text {org }}$ in the black shale and $0.10 \% \mathrm{C}_{\text {org }}$ in the green claystone).

The total extracts, normalized to organic carbon, reach values of $19 \mathrm{mg} / \mathrm{g} \mathrm{C}_{\text {org }}$, if the less accurate data of the organic-carbon-lean samples are disregarded. There is no clear downhole trend, which indicates that the organic matter in all samples is immature. There is, however, a slightly higher relative amount of total hydrocarbons (nonaromatic plus aromatic) in the more deeply buried Cretaceous samples than in Miocene and younger samples, indicating that diagenetic hydrocarbon formation is more advanced at greater depth.

Kerogen analysis by Rock-Eval pyrolysis (Espitalié et al., 1977) revealed that there are only a few samples with hydrogen index (HI) values above $100 \mathrm{mg} \mathrm{HC} / \mathrm{g} \mathrm{C}_{\text {org }}$ (Fig. 1, Table 1), i.e., those samples from lithologic Unit 8 containing more than $2 \%$ organic carbon. The position of these samples in the Rock-Eval kerogen-type diagram (Fig. 1) corresponds to Type II kerogens, at a relatively high maturity stage. This is inconsistent with the low maturity of all the organic matter in the Hole 530A sediments (see discussion to come). For the kerogens involved, either higher hydrogen (less mature Type II) or higher oxygen index (OI) values (less mature mixed Type II/III) would have been expected. The reason for

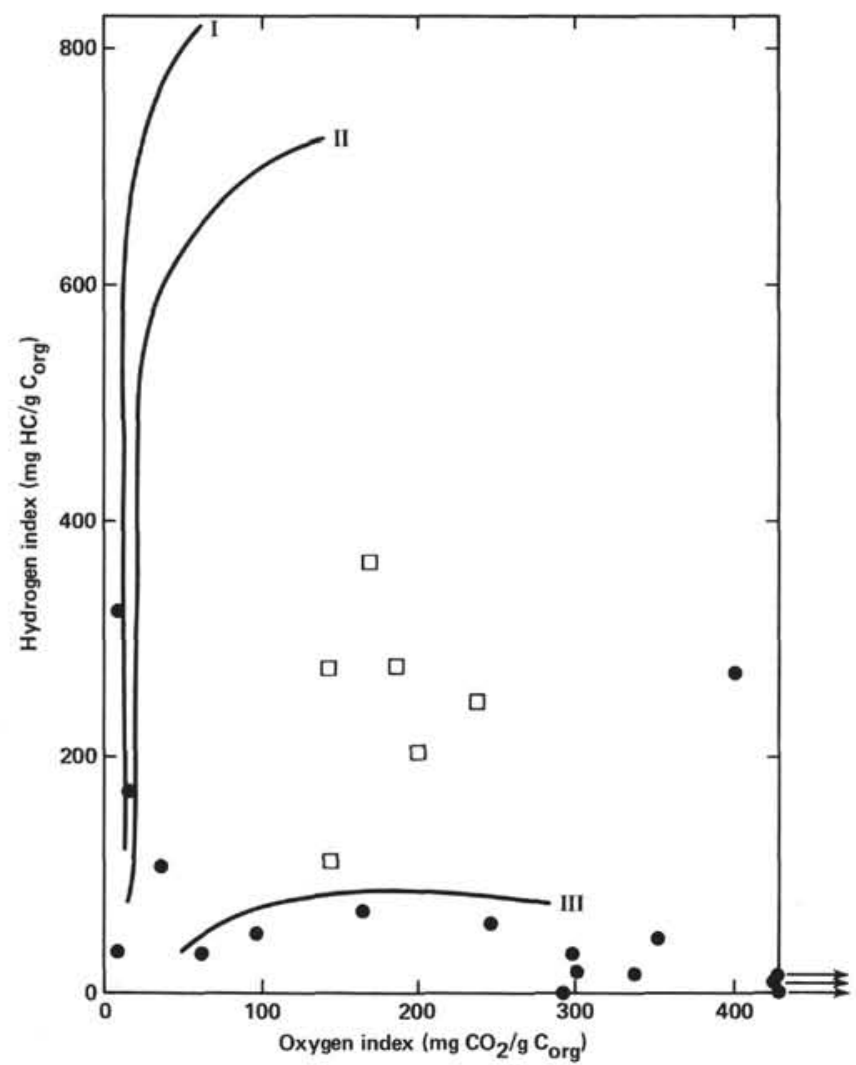

Figure 1. Results of Rock-Eval pyrolysis, displayed as hydrogen index versus oxygen index diagram (Espitalié et al., 1977) for sediment samples from DSDP Holes 530A (Angola Basin, closed circles) and 532 (Walvis Ridge, open squares). the actual results obtained is presently unknown. All the other samples from Hole 530A show low hydrogen index values and some very high oxygen index values, indicative of partly to strongly oxidized kerogen Type III organic matter. The Rock-Eval result of Sample 530A$34-6,120-135 \mathrm{~cm}$ (HI: 272 ; OI: 405 ) seems to be erroneous or affected by contamination.

\section{Kerogen Microscopy}

Maceral analysis. The composition of the insoluble organic matter was studied by transmitted light, and normal and fluorescence reflected light microscopy of smear slides, polished separated kerogens and whole rock blocks. The results for eight samples from Hole $530 \mathrm{~A}$, six of which are from the Cretaceous interval, are shown in Figure 2. The other samples were very low in organic matter, so that the amounts of kerogen isolated were insufficient for microscopic investigation.

Most of the samples analyzed contain a considerable amount of degraded amorphous organic matter. Since, in the literature, different names have been attributed to the same type of unstructured liptinite, a brief definition will be given here (cf. Gormly and Mukhopadhyay, 1983). Bituminite II (corresponding to amorphinite B of van Gijzel, 1981; bituminite I of Teichmüller and Ottenjann, 1977; or bituminite of Robert, 1981) is a mostly grainy, dark gray amorphous mass of organic matter in normal reflected light, orange to dark reddish brown (at $R_{m} \approx 0.5 \%$ ) in fluorescent light, and dark amber-yellow to light brown in transmitted light. This maceral type often contains very high amounts of framboidal pyrite. The organic matter is assumed to be either the degradation product (as obvious from some relict structures) of phyto- and zooplankton/benthos or of bacterially altered higher plant lipids.

Bituminite III (corresponding to amorphinite $\mathrm{C}$ of van Gijzel, 1981; and bituminite III of Teichmüller and Ottenjann, 1977) is also grainy, gray amorphous organic matter-sometimes with relict tissues of telinite or sporinite-in normal reflected light, showing higher reflectance than bituminite II, grayish brown to gray in fluorescent light (at $R_{m} \approx 0.5 \%$ ), and dark gray to brown in transmitted light. This type of organic matter is probably the degradation product of humic matter and higher plant liptinites (mainly sporinite).

For a description of bituminite I (degraded algae), which we did not observe in the DSDP Leg 75 samples, we refer the reader to Gormly and Mukhopadhyay (1983).

The kerogen samples from the early Pliocene and late Miocene sections 530A-5-5 and 530A-9-2 are very similar to each other and show a predominance of humic and liptinite matter derived from terrestrial higher plants. Considerable amounts of huminite/vitrinite and bimacerite grains were found, with some of the vitrinites showing oxidation rims. Pollen and zooclasts are major constituents of both samples. The inertinites with high reflectance are mostly of the inertodetrinite type (Stach et al., 1975).

Among the Cretaceous samples investigated, those from Section 530A-93-5 (997.4 m, Coniacian) and Sec- 
Table 1. Lithology, stratigraphy, organic carbon content, extract and liquid chromatography yields, and Rock-Eval pyrolysis data for core samples from Hole 530A.

\begin{tabular}{|c|c|c|c|c|c|c|c|c|c|c|c|c|c|}
\hline \multirow[b]{2}{*}{$\begin{array}{c}\text { Sample } \\
\text { (interval in } \mathrm{cm} \text { ) }\end{array}$} & \multirow[b]{2}{*}{$\begin{array}{l}\text { Depth } \\
\text { (m) }\end{array}$} & \multirow[b]{2}{*}{ Lithology } & \multirow[b]{2}{*}{ Unit } & \multirow[b]{2}{*}{$\begin{array}{l}\text { Stratigraphic } \\
\text { age }^{\mathrm{a}}\end{array}$} & \multirow[b]{2}{*}{$\begin{array}{l}\mathrm{C}_{\text {org }} \\
(\%)\end{array}$} & \multirow[b]{2}{*}{$\begin{array}{c}\text { Extract } \\
\left(\mathrm{mg} / \mathrm{g} \mathrm{C}_{\mathrm{org}}\right)\end{array}$} & \multicolumn{4}{|c|}{ Chromatographic fractions $(\%)$} & \multicolumn{3}{|c|}{$\begin{array}{l}\text { Rock-Eval } \\
\text { pyrolysis }\end{array}$} \\
\hline & & & & & & & $\begin{array}{c}\text { (nonaromatic } \\
\text { HC) }\end{array}$ & $\begin{array}{c}\text { (aromatic } \\
\text { HC) }\end{array}$ & Het.-comp. & Residue & HI & OI & $\begin{array}{l}T_{\max } \\
\left({ }^{\circ} \mathrm{C}\right)\end{array}$ \\
\hline \multicolumn{14}{|l|}{ Hole 530A } \\
\hline $5-5,120-130$ & 170.3 & Nannofossil ooze & 2 & early Pliocene & 1.00 & 19 & 3.3 & 2.5 & 66.76 & 27.5 & 69 & 168 & 398 \\
\hline $9-2,120-137$ & 203.8 & Mud-clast conglomerate & 2 & late Miocene & 1.04 & 18 & 4.4 & 1.9 & 73.8 & 19.9 & 53 & 98 & 398 \\
\hline $13-5,120-130$ & 246.3 & Nannofossil ooze & 2 & late Miocene & 0.44 & 19 & 6.2 & 4.6 & 55.4 & 33.8 & 34 & 300. & 383 \\
\hline $24-6,120-130$ & 352.3 & Clay & 3 & early Miocene & 0.44 & 9 & 4.8 & 14.3 & 47.6 & 33.3 & 22 & 301 & 393 \\
\hline $34-6,120-135$ & 447.3 & Mud & 3 & late Oligocene & 0.09 & [16] & n.d. & n.d. & n.d. & n.d. & 272 & 405 & 410 \\
\hline $37-3,120-132$ & 471.3 & Chalk & 4 & middle Eocene & 0.03 & [133] & n.d. & n.d. & n.d. & n.d. & 20 & 339 & 409 \\
\hline $43-1,130-140$ & 525.4 & Mudstone & 4 & late Paleocene & 0.10 & [40] & n.d. & n.d. & n.d. & n.d. & 5 & 933 & n.d. \\
\hline $67-1,120-132$ & 753.3 & Mudstone & 5 & Campanian & 0.03 & [59] & n.d. & n.d. & n.d. & n.d. & 1 & 582 & [493] \\
\hline $87-3,120-130$ & 944.3 & Claystone & 8 & Coniacian & 0.05 & [29] & n.d. & n.d. & n.d. & n.d. & 1 & 290 & [483] \\
\hline $89-5,120-130$ & 965.3 & Claystone & 8 & Coniacian & 0.05 & [67] & n.d. & n.d. & n.d. & n.d. & 46 & 360 & [303] \\
\hline $93-5,135-145$ & 997.4 & Claystone/black shale & 8 & Coniacian & 2.30 & 11 & 10.6 & 7.5 & 66.5 & 15.4 & 109 & 34 & 429 \\
\hline $97-3,105-110$ & 1030.1 & Black shale & 8 & Cenomanian & 10.6 & 19 & 6.9 & 7.8 & 58.9 & 26.4 & 322 & 12 & 417 \\
\hline $97-3,110-115$ & 1030.1 & Claystone & 8 & Cenomanian & 0.10 & [28] & n.d. & n.d. & n.d. & n.d. & 61 & 246 & 375 \\
\hline $99-5,0-10$ & 1050.1 & Mudstone/black shale & 8 & Cenomanian & 0.73 & 12 & 9.0 & 6.0 & 77.6 & 7.4 & 36 & 61 & 416 \\
\hline $101-3,95-105$ & 1066.0 & Mudstone & 8 & Albian-Cenomanian & 0.13 & 13 & n.d. & n.d. & n.d. & n.d. & 1 & 721 & [468] \\
\hline $103-3,110-120$ & 1084.3 & Mudstone & 8 & Albian-Cenomanian & 2.79 & 14 & 6.3 & 10.9 & 66.3 & 16.5 & 170 & 18 & 427 \\
\hline $105-1,90-100$ & 1095.0 & Mudstone & 8 & Albian-Cenomanian & 0.82 & 19 & 9.7 & 7.3 & 57.0 & 26.0 & 38 & 9 & 415 \\
\hline
\end{tabular}

Note: Values in brackets denote unreliable data because of very low organic carbon contents; n.d. = not determined.

a Revisions of stratigraphic ages are given in Steinmetz et al., this volume.

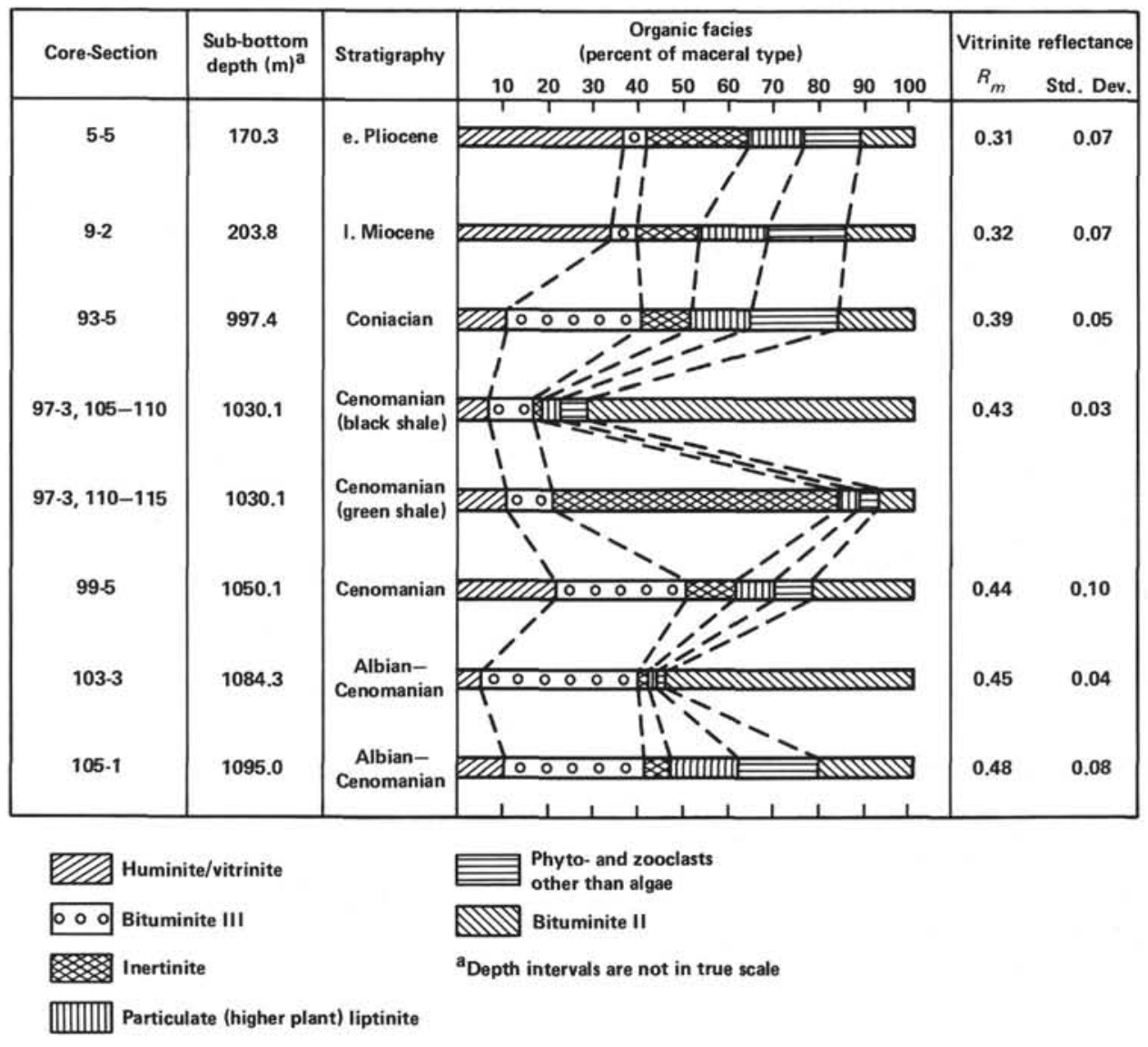

Figure 2. Maceral composition and mean vitrinite reflectance values for sediment samples from DSDP Hole 530A (Angola Basin). (Revisions of stratigraphic ages are given in Steinmetz et al., this volume.)

tion 530A-99-5 (1050.1 m, Cenomanian) resemble each other, both in transmitted and reflected light. They contain neutral gray-black amorphous humic and liptinite material as dominant macerals (bituminite III and II), often enriched with organo-pyrite, which in some cases show pseudomorphism on plant tracheids, pollen, and bryozoan fragments. Another major component in both samples is sporinite from pollen and spores (Plate 1, Fig. 3). The Cenomanian kerogen (530A-99-5) is enriched in both autochthonous $(0.25-0.65 \%$ reflectance $)$ and recycled vitrinite $(0.75-1.55 \%$ reflectance), the latter showing oxidation rims and bimacerite grains. In contrast to 
this, very few recycled vitrinite particles were observed in Section 530A-93-5 (Coniacian). The overall composition of both samples indicates a dominant contribution of terrigenous organic matter mixed with a minor component of marine origin.

The Cenomanian black shale (Sample 530A-97-3, $105-110 \mathrm{~cm}$ ) contains more than $80 \%$ mixed amorphous organic matter. In transmitted light, there is a mixture of amber yellow and gray-black amorphous organic matter (Plate 1, Figs. 1, 4, 5), with some slightly degraded and some intact dinoflagellates (Plate 1, Figs. 1, 5). In reflected light, dark gray bituminite II (Plate 1, Fig. 2) dominates, bearing a high content of organo-pyrite pseudomorphs (observed in whole rock specimen) on zoo- and phytoplankton and occasionally on pollen grains. Fluorescent reflected light predominantly shows reddish brown bituminite II. In summary, this kerogen is of mixed marine and terrigenous origin with phytoand zooplankton dominating. Colonial or unicellular algae with grain boundaries are absent.

The Cenomanian green claystone, Sample 530A-97-3, $110-115 \mathrm{~cm}$, which is from the lower contact of the black shale discussed above contains a mainly fusinized amorphous organic matter with subordinate organo-pyrite. Dominant macerals in normal reflected light are granular micrinite and degradoinertinite (Stach et al., 1975).

The late Albian-early Cenomanian gray shale from Section 530A-103-3 (1084.3 m) has a kerogen similar in appearance to that of the Cenomanian black shale. Gray bituminite III (Plate 1, Fig. 6) and bituminite II (Plate 1, Fig. 7) with a very high content of framboidal pyrite dominate in normal reflected light. A few liptinite particles are seen in addition to the bulk dark gray amorphous organic matter in transmitted light,

The purple gray shale of late Albian-early Cenomanian age (Section 530A-105-1) contains a mixture of bituminite III, bituminite II, sporinite, and phyto- and zooclasts (Plate 1, Figs. 7, 8). The dominant source for this organic matter is terrestrial higher plants.

In Figure 3 the results of the maceral analysis are correlated with the hydrogen index values of the Rock-Eval pyrolysis. Three groups of organic-matter types can be distinguished. The Cenomanian black shale is richest in marine macerals and hydrogen, although for a Type II kerogen (cf. Tissot and Welte, 1978), with the given ratio of marine versus terrigenous organic matter, the hydrogen index value appears to be unusually low. The sample from Section 530A-103-3 contains a mixed kerogen of Type II-III, whereas all other samples from Hole $530 \mathrm{~A}$ contain a dominance of terrigenous organic matter which is partly oxidized, resulting in low hydrogen index values. Only the Type II-III and Type II kerogen samples bear a significant petroleum generation potential.

Maturity. Figure 4 shows reflectance histograms of autochthonous (primary) and recycled huminite/vitrinite particles. All histograms are multimodal, and the boundary between the two huminite/vitrinite types in each case was determined by measuring the reflectance of scleroti-

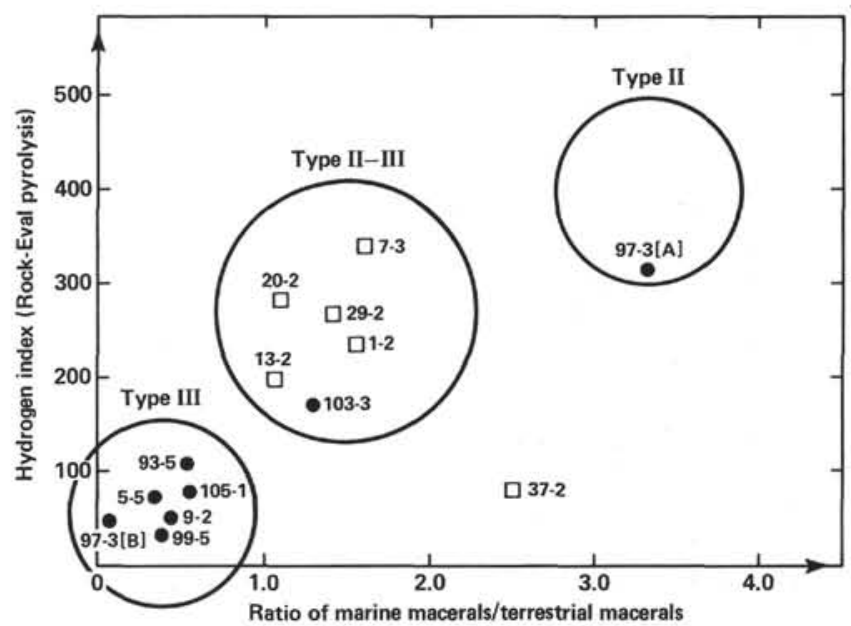

Figure 3. Plot of hydrogen index (HI) values from Rock-Eval pyrolysis versus the ratio of marine to terrestrial macerals for selected sediment samples from DSDP Holes 530A (closed circles) and 532 (open squares). For Section 97-3, A and B denote upper (black shale) and lower (green shale) part of Sample 530A-97-3, 105-115 $\mathrm{cm}$ (see text and Table 1).

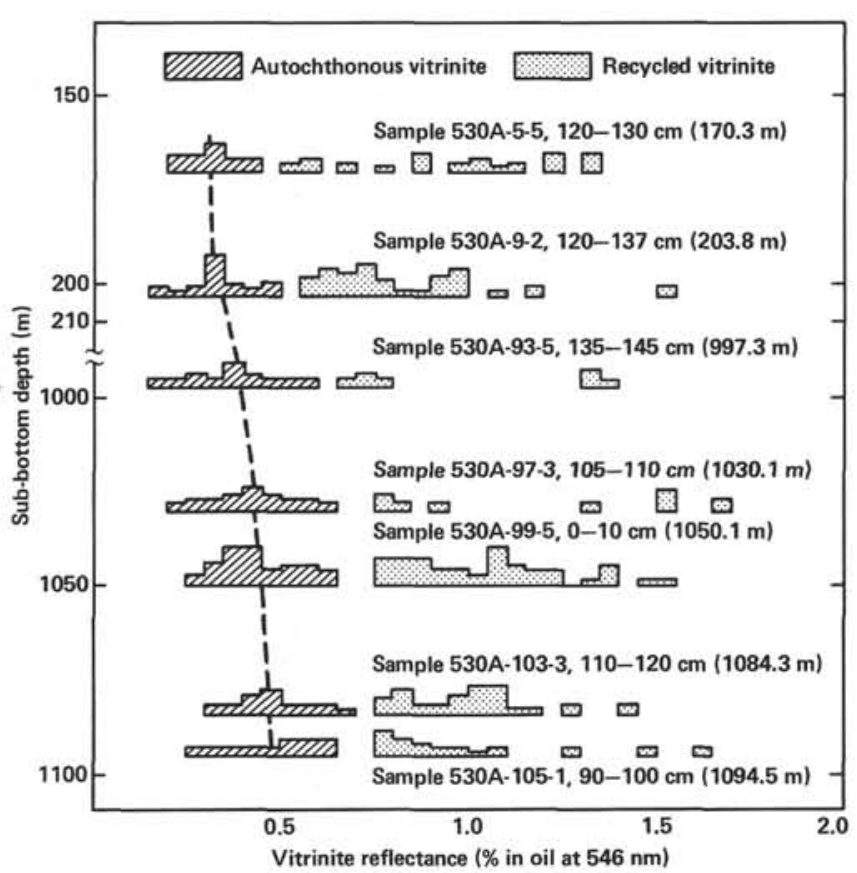

Figure 4. Reflectance histograms of autochthonous (primary) and recycled vitrinite/huminite for sediment samples from DSDP Hole 530A (Angola Basin).

nite, vitrinite in bimacerites, or oxidized vitrinite-the reflectance of autochthonous vitrinite being lower than that of those macerals. Except in Sections 530A-93-5 and 530A-97-3, high amounts of recycled vitrinite were found with reflectance values up to $1.7 \% R_{m}$. The mean vitrinite reflectance values (see Fig. 2) increase from $0.31 \%$ to $0.48 \% R_{m}$ between 169 and $1094 \mathrm{~m}$ depth, indicating low maturity of the organic matter over the entire interval. 


\section{Nonaromatic Hydrocarbon Composition}

With the organic-carbon-rich black shale sample (Sample 530A-97-3, 105-110 cm) as the only exception, all nonaromatic hydrocarbon distributions are dominated by n-alkanes (Fig. 5 A-H; Table 2). Within the $\mathrm{C}_{15}+\mathrm{n}$-alkanes, the long-chain members with 29, 31, and 33 carbon atoms predominate in all samples. The maximum is at $\mathrm{n}-\mathrm{C}_{31}$ in each case, and there is only a slight decrease in even-over-odd carbon-number predominance down the hole (cf. Figs. 5A and 5B).

A series of $17 \beta(\mathrm{H})$-hopanes $\left(\mathrm{C}_{27}, \mathrm{C}_{29}-\mathrm{C}_{32}\right.$; maximum at $\mathrm{C}_{31}$ ) are the only cyclic hydrocarbons present in significant, albeit low, concentrations in the moderately organic-carbon-rich Miocene and younger sediments from Hole 530A (Fig. 5A). In addition, traces of $\mathrm{C}_{27}$ to $\mathrm{C}_{29}$ ster-4-enes and ster-5-enes, hop-17(21)-ene, fern-8ene, fern-9(11)-ene, and $17 \alpha(\mathrm{H})$-hopanes $\left(\mathrm{C}_{27}, \mathrm{C}_{29}, \mathrm{C}_{30}\right)$ could be detected by gas chromatography/mass spectrometry (see chapter appendix for compound structures). The organic-carbon-lean sediments, represented by Samples 530A-87-3, 120-130 cm (Coniacian; Fig. 5B) and 530A-97-3, 110-115 cm (Cenomanian; Fig. 5E), are nearly devoid of any nonaromatic hydrocarbons, except $\mathrm{n}$-alkanes and some pristane and phytane.

The nonaromatic hydrocarbon compositions of those sediment samples from lithologic Unit 8 containing between 0.7 and $2.8 \% C_{\text {org }}$, i.e., Samples 530A-93-5, $135-145 \mathrm{~cm}$ (Coniacian; Fig. 5C); 530A-99-5, 0-10 cm (Cenomanian; Fig. 5F); 530A-103-3, 110-120 cm (Albian-Cenomanian; Fig. 5G); and 530A-105-1, 90-100 cm (Albian-Cenomanian; Fig. 5H), are similar to each other with respect to the type of compounds present, although there are distinct variations in relative concentrations. The content of cyclic compounds relative to n-alkanes does not always follow the total organic carbon trend;

Table 2. Nonaromatic hydrocarbons identified by their mass spectra and relative retention times in sediments from DSDP Holes 530A and 532 (cf. Figs. 5 and 12).

\begin{tabular}{|c|c|c|}
\hline & $=$ pristane & $\mathrm{w}=24$-methylcholesta-4,22-diene \\
\hline & $=$ phytane & $x=24$-methylcholesta-5,22-diene \\
\hline & $=$ phytenes & $y=17 \alpha(H)-22,29,30$-trisnorhopane \\
\hline & $=\mathrm{C}_{25}$ isoprenoid & $\mathrm{z}=17 \beta(\mathrm{H})-22,29,30$-trisnorhopane \\
\hline & $=$ unknown $\mathrm{C}_{27}$ sterene & $a^{\prime}=$ unknown $\left(M^{+} 410\right.$, BP 395$)$ \\
\hline d & $=\mathrm{C}_{27}$ diasterene & $b^{\prime}=30$-norhop-13(18)-ene \\
\hline & $=$ unknown $\mathrm{C}_{28}$ sterene & $c^{\prime}=24$-ethylcholest-4-ene \\
\hline f & $=\mathrm{C}_{27}$ diasterene & $\mathrm{d}^{\prime}=17 \alpha(\mathrm{H})-30$-norhopane \\
\hline g & $=\mathrm{C}_{27}$ diasterene & $\mathrm{e}^{\prime}=$ 24-ethylcholest-5-ene \\
\hline & $=\mathrm{C}_{27}$ diasterene & $\mathrm{f}^{\prime}=24$-ethyl- $5 \alpha(\mathrm{H})$-cholestane \\
\hline & $=$ unknown $\mathrm{C}_{27}$ sterene & $\mathrm{g}^{\prime}=30$-norhop-17(21)-ene \\
\hline & $=$ unknown $\left(M^{+}+398\right.$, BP 231) & $h^{\prime}=$ hop-17(21)-ene \\
\hline k & $=$ squalane(?) & $\mathrm{i}^{\prime}=30$-normoretane \\
\hline 1 & $=\mathrm{C}_{28}$ diasterene & $\mathrm{j}^{\prime}=17 \alpha(\mathrm{H})$-hopane \\
\hline m & $=\mathrm{C}_{28}$ diasterene & $\mathrm{k}^{\prime}=$ fern-8-ene \\
\hline $\mathbf{n}$ & $=\mathrm{C}_{28}$ diasterene & $1^{\prime}=$ hop-13(18)-ene \\
\hline o & $=$ unknown $\mathrm{C}_{29}$ sterene & $\mathrm{m}^{\prime}=30$-nor-17$\beta(\mathrm{H})$-hopane \\
\hline p & $=$ unknown (BP 231) & $\mathrm{n}^{\prime}=$ fern- $9(11)$-ene \\
\hline q & $=\mathrm{C}_{29}$ diasterene & $0^{\prime}=C_{30} \Delta^{12}$-triterpene \\
\hline $\mathrm{r}$ & $=\mathrm{C}_{29}$ diasterene & $\mathrm{p}^{\prime}=$ fern-7-ene \\
\hline s & $=$ cholest-4-ene & $\mathrm{q}^{\prime}=17 \beta(\mathrm{H})$-hopane \\
\hline $\mathrm{t}$ & $=\mathrm{C}_{29}$ diasterene & $\mathrm{r}^{\prime}=17 \beta(\mathrm{H})$-homohopane \\
\hline $\mathbf{u}$ & $=$ cholest-5-ene & $\mathrm{s}^{\prime}=17 \beta(\mathrm{H})$-bishomohopane \\
\hline $\mathbf{v}$ & $=5 \alpha(\mathrm{H})$-cholestane & \\
\hline
\end{tabular}

Note: $\mathrm{BP}=$ base peak e.g., the highest relative concentration of cyclic nonaromatic hydrocarbons is found in Sample 530A-105-1, 90-100 cm (Fig. $5 \mathrm{H}$ ) with only $0.82 \mathrm{C}_{\text {org }}$. Rearranged sterenes $\left(\mathrm{C}_{27}-\mathrm{C}_{29}\right)$ are the only steroid hydrocarbons present, and these are less abundant than triterpenoid hydrocarbons. $17 \beta(\mathrm{H})$-hopanes $\left(\mathrm{C}_{27}, \mathrm{C}_{29}-\mathrm{C}_{32}\right)$ are still abundant in the deepest sample from $1095.0 \mathrm{~m}$ (Fig. $5 \mathrm{H}$ ) which, however, also contains $17 \alpha(\mathrm{H})$-trisnorhopane in unusually high concentration. Triterpenes are common in all the samples discussed here and compose a series of hop-17(21)-enes $\left(C_{27}, C_{29}^{\prime}, C_{30}\right)$, hop-13(18)-enes $\left(C_{27}\right.$ ?, $C_{29}, C_{30}$ ), fern-8-ene, fern-9(11)-ene, and a $\Delta^{12}$-triterpene. An unknown major compound $\left(\mathrm{a}^{\prime}\right.$ in Fig. 5 may also be a $\mathrm{C}_{30}$-triterpene (molecular ion at $\mathrm{m} / \mathrm{z} 410$, base peak $\mathrm{m} / \mathrm{z} 395$ ).

The Cenomanian black shale, Sample 530A-97-3, 105$110 \mathrm{~cm}$, differs from the other samples from Unit 8 in the fact that phytane and pristane are the dominant compounds in the nonaromatic hydrocarbon fraction, and steroids and triterpenoids are abundant in the higher molecular weight range (Fig. 5D). The distribution of triterpenes and triterpanes present are qualitatively similar to the other samples from lithologic Unit 8, but with the exception of the unknown compound $\mathrm{a}^{\prime}$, are less abundant than the steroid hydrocarbons; among the latter, the rearranged sterenes have the highest concentration (Fig. 6). In addition 4-methyl rearranged sterenes $(\mathrm{m} / \mathrm{z} 271)$ and diunsaturated compounds $(\mathrm{m} / \mathrm{z} 269)$ add to the complex sterene pattern (Fig. 6). $\mathrm{C}_{27}$ and $\mathrm{C}_{29}$ ster4-enes and ster-5-enes $(\mathrm{m} / \mathrm{z} 215)$ are minor constituents, as are the saturated $\mathrm{C}_{27}$ to $\mathrm{C}_{29} 5 \alpha(\mathrm{H})$ - and $5 \beta(\mathrm{H})$-steranes (m/z 217; Fig. 6).

\section{Aromatic Hydrocarbon Composition}

Six aromatic hydrocarbon fractions of sediments from Hole 530A were analyzed in detail; the results are shown in Figures $7 \mathrm{~A}-\mathrm{F}$ and Table 3. The late Miocene Sample $530 \mathrm{~A}-9-2,120-130 \mathrm{~cm}$ contains different compounds from those present in samples from lithologic Unit 8; three different alkylated thiophenes are major constituents. The mass spectra of two isomeric $\mathrm{C}_{20}$ thiophenes are shown in Figure 8; they are consistent with the general fragmentation pattern of alkylated thiophenes (Kinney and Cook, 1952; Pomonis et al., 1976). A tentative structure of 2-pentadecanyl-3-methylthiophene was assigned for one isomer, where the pentadecanyl substituent may be a straight chain or branched, although not at the benzylic position. The second thiophene is monosubstituted. The formation of the main fragment at $\mathrm{m} / \mathrm{z}$ 98 is supposed to result from a McLafferty rearrangement common in long-chain alkylated aromatics unless both ortho-positions are devoid of hydrogens, as in the case of the first isomer (Budzikiewicz et al., 1967), although in the mass spectra of 2-n-tridecanyl- and 2-nheptadecanyl-thiophene published by Pomonis et al. (1976) the $\mathrm{m} / \mathrm{z} 98$ fragment shows only half the abundance of the $\mathrm{m} / \mathrm{z} 97$ fragment. The extent of rearrangement vs. cleavage products may, however, depend on instrumental parameters. The mass spectrum of the third alkylated thiophene $\left(\mathrm{C}_{27} ; 49\right.$ in Fig. 7A) has been reported previously (Rullkotter, von der Dick, and Welte, 
A
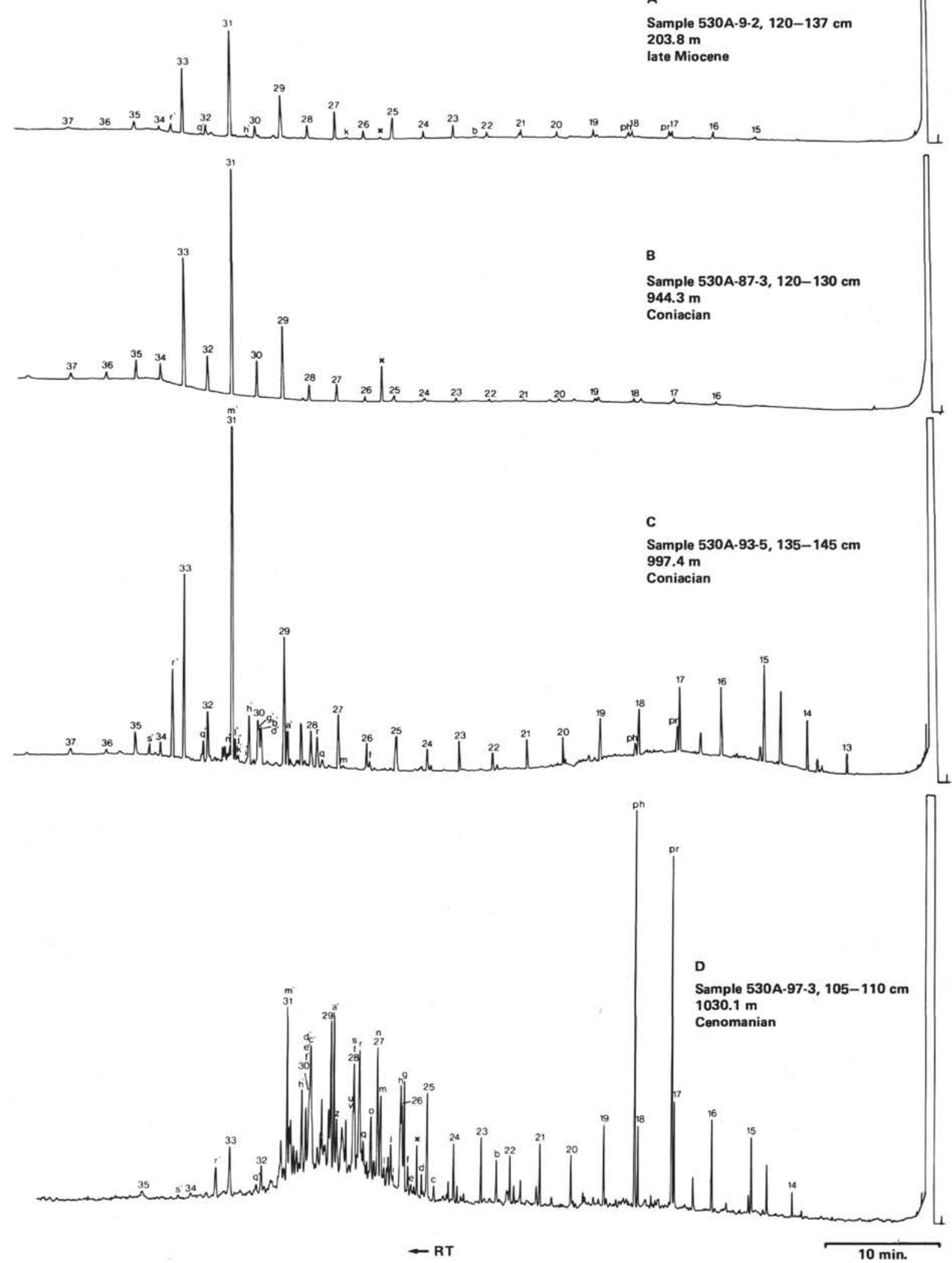

Figure 5. Capillary column gas chromatograms of the nonaromatic hydrocarbon fractions of selected sediment samples from DSDP Hole 530A (Angola Basin). Numbers indicate $n$-alkanes, compounds marked with letters are listed in Table 2, pr $=\mathrm{pris-}$ tane, $\mathrm{ph}=$ phytane, $\mathrm{x}=$ phthalate ester contaminant. Analytical conditions: $25 \mathrm{~m}$ fused silica capillary column coated with SE 54; temperature program: $100^{\circ}-300^{\circ} \mathrm{C}$ at $3^{\circ} \mathrm{C} / \mathrm{min}$.; slightly different conditions for chromatogram in Figure 5D (wider bore glass capillary column, temperature program $80-250^{\circ} \mathrm{C}$ ). (Revisions of stratigraphic ages are given in Steinmetz et al., this volume.) 

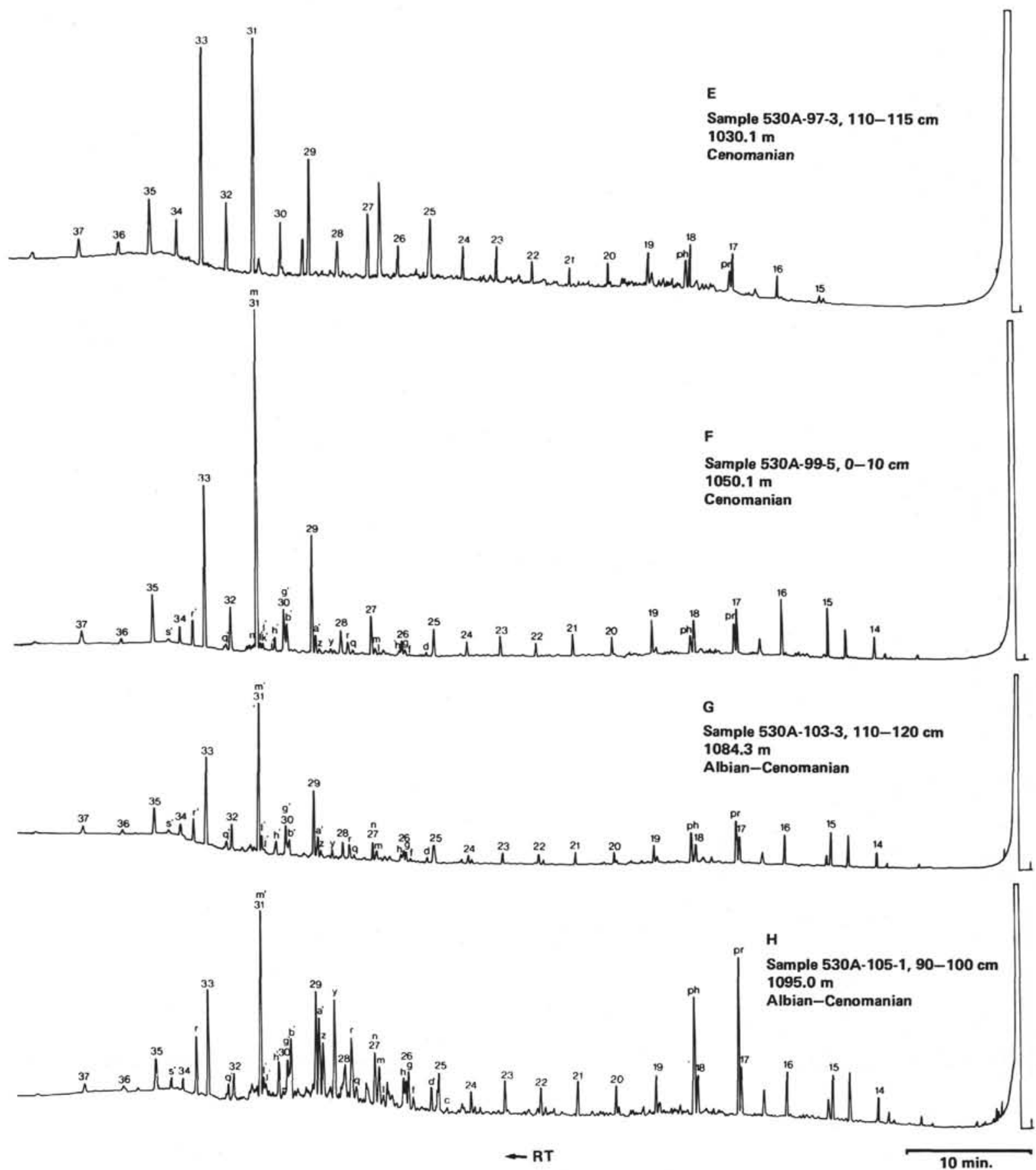

Figure 5. (Continued).

1982). The late Miocene sample is the only one from Hole $530 \mathrm{~A}$ containing significant amounts of perylene. Two isomeric tetramethyloctahydrochrysenes probably derived from oxidation products of pentacyclic triterpenoids which have lost their A-ring (Spyckerelle et al., 1977a,b). Two further aromatic hydrocarbons have molecular weights of 326 and 310, respectively. They could not be identified with certainty, although the latter may be a monoaromatic pentamethyldodecahydrochrysene tentatively identified in Messel oil shale by Spyckerelle et al. (1977a).
The Cretaceous sediments from lithologic Unit 8 have aromatic hydrocarbon compositions similar to each other, with the exception of the black shale, Sample 530A-97-3, 105-110 cm (Figs. 7B-F). The black shale shows a complex, poorly resolved aromatic hydrocarbon mixture in the lower molecular weight range (Fig. 7C), with only one major peak which gives a mass spectrum virtually identical with that of 1,1,6-trimethyl1,2,3,4-tetrahydronaphthalene (ionene). In the higher molecular weight range, monoaromatic steroid hydrocarbons dominate. In addition to some unknown com- 


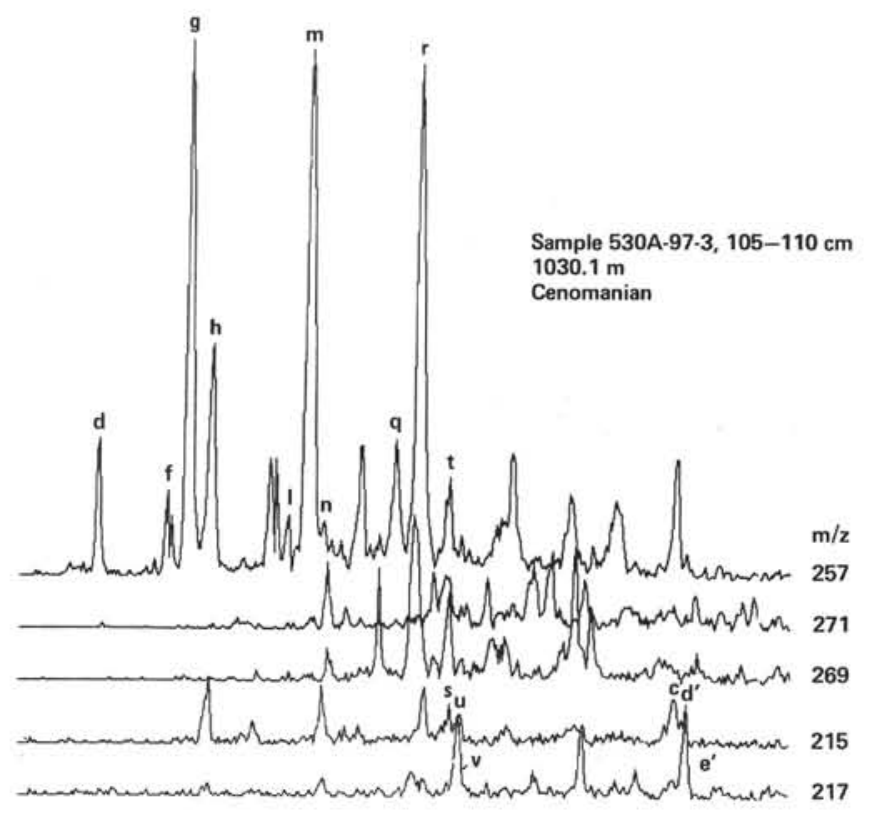

$\mathrm{RT} \rightarrow$

Figure 6. Mass fragmentograms of key fragment ions of steroid hydrocarbons in the nonaromatic hydrocarbon fraction of the black shale Sample 530A-97-3, 105-110 cm (see text). Compounds marked with letters are listed in Table 2. (Revisions of stratigraphic ages are given in Steinmetz et al., this volume.)

pounds (41, 56 in Fig. 7C), tetracyclic monoaromatic compound (27), found before in the Messel oil shale (Spyckerelle, 1977a), and the hopanoid-derived 7-methyl-3' -ethyl-1,2-cyclopentanochrysene (54) were detected in significant amounts.

The other four Cretaceous samples contain a greater number of resolved compounds of which nordehydroabietane (16), coeluting with minor amounts of pyrene (17), and the tetracyclic mono-aromatic triterpenoid derivative (27) are dominant in all samples; others, like ionene (3) and the unknown compounds 41 and 56, show considerable variation in concentration (Figs. 7B, D-F). The aromatic steroid hydrocarbon distribution of Sample 530A-103-3, 110-120 cm is shown in Figure 9. Ring C monoaromatic steroids ( $\mathrm{m} / \mathrm{z} 253$ ) dominate; the carbon number distribution was determined from chemical ionization $\mathrm{gc} / \mathrm{ms}$ measurements (A. S. Mackenzie, pers. comm.), and from data in an earlier publication by Mackenzie et al. (1981). A similar pattern was obtained for the related desmethyl compounds $(\mathrm{m} / \mathrm{z} 239)$, whereas the $\mathrm{m} / \mathrm{z} 267$ mass fragmentogram, formally representing methylated compounds, is more complex. The ring $\mathbf{A}$ and ring $\mathbf{B}$ monoaromatic steroid hydrocarbons which are less stable than the C-ring aromatic analogs (Rullkötter and Welte, 1983) are present in relatively lower concentration as $\mathrm{C}_{27}$ to $\mathrm{C}_{29}$ homologs. 4-Methylstera$1,3,5(10)$-trienes are characterized by the $\mathrm{m} / \mathrm{z} 158 \mathrm{frag}$ ment (Hussler et al., 1981; Rullkötter and Welte, 1983), whereas the two earlier eluting compounds in the $\mathrm{m} / \mathrm{z}$ 211 fragmentogram may be anthrasteroids (Rullkötter and Welte, 1983). Triaromatic steroid hydrocarbons are represented by the $\mathrm{m} / \mathrm{z} 231$ trace, and an additional methylated series having an m/z 245 key fragment is also present (not shown in Fig. 9).

\section{RESULTS: HOLE 532, WALVIS RIDGE}

The total organic carbon content of Pliocene to Pleistocene sediments from DSDP Hole 532 are consistently high, with a variation between 1.92 and $4.40 \%$ (Table 3 ). Rock-Eval pyrolysis indicates a mixed Type II/Type III (planktonic/terrestrial higher plant) kerogen with little variation for all samples, except the deepest of early Pliocene age, which has a lower hydrogen index and would be classified as Type III kerogen (Fig. 1). The total extracts, normalized to organic carbon, show a clear difference between the Pleistocene (ca. $10 \mathrm{mg} / \mathrm{g} \mathrm{C}_{\text {org }}$ ) and Pliocene sediments (ca. $20 \mathrm{mg} / \mathrm{g} \mathrm{C}_{\text {org }}$ ), although a maturation effect cannot be expected over the short distance and from the small age difference.

\section{Kerogen Microscopy}

Maceral analysis. The maceral composition of the Hole 532 samples, derived from transmitted and reflected light microscopy, is shown in Figure 10. Petrographic data indicate that all six kerogens are similar in appearance and composition. More than $75 \%$ of the organic matter in each case is composed of degraded, amorphous bituminite II and III, with bituminite II being more than $50 \%$, except in Section 532-13-2. Plate 1, Figure 12 shows the bituminite II in Sample 432-37-2, 110-120 cm; this sediment is richest in this type of organic matter. In general, all kerogens show a grainy gray mass of organic matter with a high concentration of framboidal pyrite. Some samples contained relict degraded dinoflagellates. The content of huminite/vitrinite and inertinite particles is low throughout. The maceral composition plotted against the hydrogen index of the Rock-Eval pyrolysis classifies all kerogens as mixed marine/terrigenous (Type II-III), with only the sample from Section 53237-2 having a lower hydrogen index value than expected from the maceral composition (Fig. 4).

Maturity. The reflectance histograms of autochthonous (primary) and recycled huminite/vitrinite (Fig. 11) exhibit multimodal distributions, as in the Angola Basin samples from DSDP Hole 530A. For the fragmentary vitrinites in Section 532-20-2, reliable reflectance measurements could not be achieved. The mean huminite/ vitrinite reflectance values show a slight increase with depth (Fig. 10), but indicate that the organic matter is immature in all samples.

\section{Nonaromatic Hydrocarbon Composition}

The $n$-alkane distributions of all samples from Hole 532 exhibit major similarities. Terrigenous influence is demonstrated by the dominance of long chain-length wax alkanes (Eglinton and Hamilton, 1963), with a maximum at $n-\mathrm{C}_{31}$ and a high odd-over-even carbon number predominance (Fig. 12). Isoprenoid hydrocarbons are represented by small amounts of pristane, phytane, a $\mathrm{C}_{25}$-isoprenoid and, in one sample, probably squalane. In addition, the more deeply buried samples contain some phytenes (Figs. 12C and D). Cyclic hydrocarbons are also minor constituents and predominantly consist 
Table 3. Lithology, stratigraphy, organic carbon content, extract and liquid chromatography yields, and Rock-Eval pyrolysis data.

\begin{tabular}{|c|c|c|c|c|c|c|c|c|c|c|c|c|}
\hline \multirow[b]{2}{*}{$\begin{array}{c}\text { Sample } \\
\text { (interval in } \mathrm{cm} \text { ) }\end{array}$} & \multirow[b]{2}{*}{$\begin{array}{l}\text { Depth } \\
\text { (m) }\end{array}$} & \multirow[b]{2}{*}{ Lithology } & \multirow[b]{2}{*}{$\begin{array}{l}\text { Stratigraphic } \\
\text { age }\end{array}$} & \multirow[b]{2}{*}{$\begin{array}{l}\mathrm{C}_{\text {org }} \\
(\%)\end{array}$} & \multirow[b]{2}{*}{$\begin{array}{c}\text { Extract } \\
\text { (mg/g C } \mathrm{Corg}_{\text {org }}\end{array}$} & \multicolumn{4}{|c|}{ Chromatographic fractions (\%) } & \multicolumn{3}{|c|}{$\begin{array}{c}\text { Rock-Eval } \\
\text { pyrolysis }\end{array}$} \\
\hline & & & & & & $\begin{array}{c}\text { Nonaromatic } \\
\text { HC }\end{array}$ & $\begin{array}{c}\text { Aromatic } \\
\text { HC }\end{array}$ & Het.-comp. & Residue & HI & OI & $\begin{array}{l}T_{\max } \\
\left({ }^{\circ} \mathrm{C}\right)\end{array}$ \\
\hline \multicolumn{13}{|l|}{ Hole 532} \\
\hline $1-2,110-120$ & 2.7 & Nannofossil-foraminiferal ooze & late Pleistocene & 2.76 & 10 & 3.4 & 1.3 & 72.5 & 22.8 & 247 & 239 & 394 \\
\hline $7-9,90-100$ & 29.5 & Foraminiferal-nannofossil ooze & early Pleistocene & 4.40 & 12 & 5.4 & 0.5 & 88.7 & 5.4 & 361 & 171 & 395 \\
\hline $13-2,90-100$ & 54.9 & Diatomaceous-nannofossil marl & early Pleistocene & 3.07 & 10 & 6.1 & 0.9 & 23.6 & 69.4 & 208 & 194 & 394 \\
\hline $20-2,120-130$ & 86.0 & Nannofossil-diatomaceous marl & late Pliocene & 3.59 & 19 & 0.4 & 0.2 & 55.4 & 44.0 & 286 & 140 & 395 \\
\hline $29-2,90-100$ & 123.3 & Nannofossil marl & late Pliocene & 3.92 & 20 & 1.3 & 1.1 & 63.1 & 34.5 & 281 & 184 & 394 \\
\hline $37-2,110-120$ & 153.3 & Foraminiferal-nannofossil ooze & early Pliocene & 1.92 & 19 & 2.5 & 1.4 & 76.2 & 19.9 & 109 & 142 & 393 \\
\hline
\end{tabular}

of $17 \beta(\mathrm{H})$-hopanes and triterpenes. Sterenes and steradienes are present in the two deepest samples, whereas diasterenes could not be detected. The early Pliocene sample, Sample 532-37-2, 110-120 cm, contains a series of unknown isomeric compounds with $\mathrm{m} / \mathrm{z} 231$ as the only major ion in their mass spectra.

\section{Aromatic Hydrocarbon Composition}

Three samples from Hole 532 were analyzed for their aromatic hydrocarbon distributions, and there is a clear difference between the shallowest Pleistocene sample (Sample 531-1-2, 110-120 cm; $2.7 \mathrm{~m}$ ) and the Pliocene sediments (Fig. 13). The former apparently contains a number of nitrogen-bearing aromatics as major components $(19,30-32)$ according to their odd-mass molecular ion peaks (Fig. 13A; Table 4). Alkyl thiophenes (20, 21, $40,49)$ are common in all samples, although in Sample $532-1-2,110-120 \mathrm{~cm}$ only the $\mathrm{C}_{25}$-compound (40) could be detected. A number of steroid hydrocarbons, with various degrees of unsaturation, are dominant in the higher molecular weight region of the Pliocene samples (Figs. 13B and C). Some of them have mass spectra resembling sterenes and might have been expected to occur in the nonaromatic hydrocarbon fraction. Perylene (43) is present in samples from the Pliocene in significant concentration.

\section{DISCUSSION: HOLE 530A, ANGOLA BASIN}

\section{Organic Facies}

The results of the organic geochemical and organic petrographic investigation of the DSDP Leg 75 core samples from Hole 530A in the Angola Basin indicate that the environmental conditions were highly variable with respect to organic matter preservation over the time span covered, i.e., from the middle Cretaceous to the late Tertiary. The Coniacian (Core 530A-89) through Oligocene sediments are poor in organic matter and represent typical deep-sea sediments deposited in oxidizing water (Table 1). The residual organic matter present consists of highly oxidized, inert material predominantly of terrigenous origin, as shown by Rock-Eval pyrolysis (Fig. 1; Table 1; Welte et al., 1979). The nonaromatic hydrocarbon fractions (e.g., Fig. 5B) contain mostly n-alkanes, with a distribution typical of higher plant waxes (Eglinton and Hamilton, 1963). These compounds are known to survive long distal transport into the deepsea area (e.g., Rullkötter et al., 1980; Rullkötter, Cornford, Welte, 1982).
The Miocene and Pliocene sediments have organic carbon contents between 0.4 and $1.0 \%$ (Table 1), and contain organic matter of predominantly terrigenous origin which is slightly better preserved than in the Coniacian through Oligocene sediments previously described. Kerogen microscopy reveals the presence of only 20-30\% marine organic matter (Fig. 2), and RockEval pyrolysis (Fig. 1, Table 1) supports this by yielding low hydrogen index values and high oxygen index values around $300 \mathrm{mg} \mathrm{CO} / \mathrm{g} \mathrm{C}_{\mathrm{org}}$. The nonaromatic hydrocarbon fractions (e.g., Figure 5A) are dominated by n-alkanes derived from terrestrial higher plants. Small amounts of cyclic compounds are mainly triterpanes of the $17 \beta(\mathrm{H})$-hopane type and indicate partial microbial reworking of the organic matter at the time of deposition (Ourisson et al., 1979). The late Miocene sample, 530A-9-2, 120-137 cm (Fig. 7A) contains, in addition to the thiophenes of unknown significance, two degraded triterpanes of the octahydrochrysene type as major compounds of the aromatic hydrocarbon fraction. These are thought to be derived from oxidative degradation of 3-oxo triterpenoids (Corbet et al., 1980) common in terrestrial higher plants. This further confirms that the African continent was the main source of organic matter in these sediments, and that the organic matter underwent partial oxidation during transport. The Benguela upwelling current, which started in the Miocene, apparently has not had a pronounced effect on the Miocene/Pliocene sediments at Site 530 in the Angola Basin. This means that the oxygen minimum zone usually associated with high bioproductivity in areas of coastal upwelling did not extend far enough, either laterally or vertically, to cause a significant preservation of the autochthonous marine biomass at this site. Compared with the organiccarbon-lean Coniacian through Oligocene sediments at this site, the better preservation of the organic matter may be the result of higher sedimentation rates and rapid burial into turbidity deposits, probably originating from the nearby Walvis Ridge (cf. site summary, this volume).

The middle Cretaceous sequence with alternating organic-carbon-rich black shales and organic-carbon-lean claystones illustrates two extreme modes of deposition and preservation of organic matter in the deep sea. The organic-carbon-lean claystones, exemplified by the $\mathrm{Ce}$ nomanian sample, Sample 530A-97-3, 110-115 cm, bear the same characteristics as the Coniacian through Oligocene sediments described before, which all contain residuary amounts of organic matter below $0.1 \%$. The Ceno- 
A

Sample 530A-9-2, 120-137 cm

$203.8 \mathrm{~m}$

late Miocene

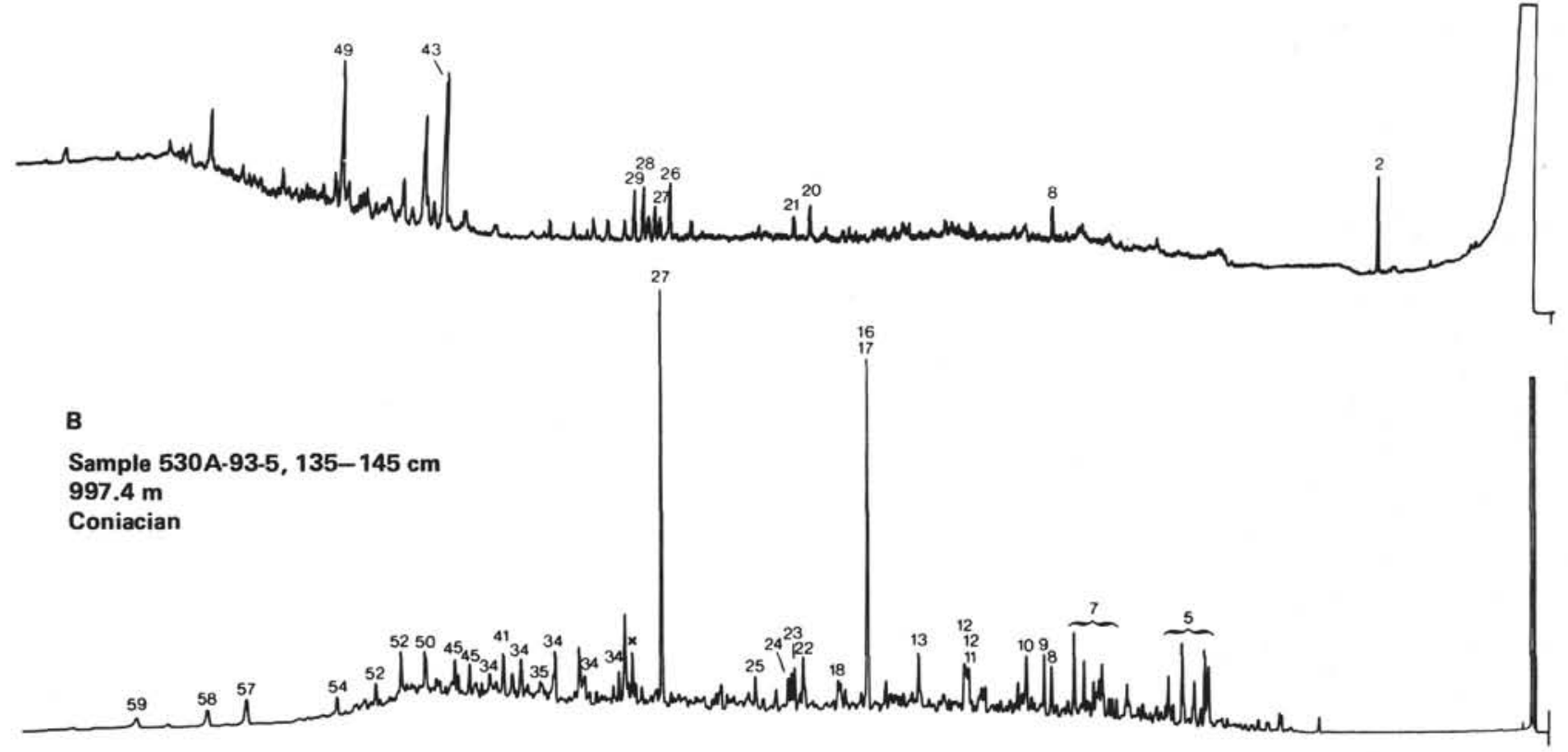

C

Sample 530A-97-3, 105-110 cm

$1030.1 \mathrm{~m}$

Cenomanian

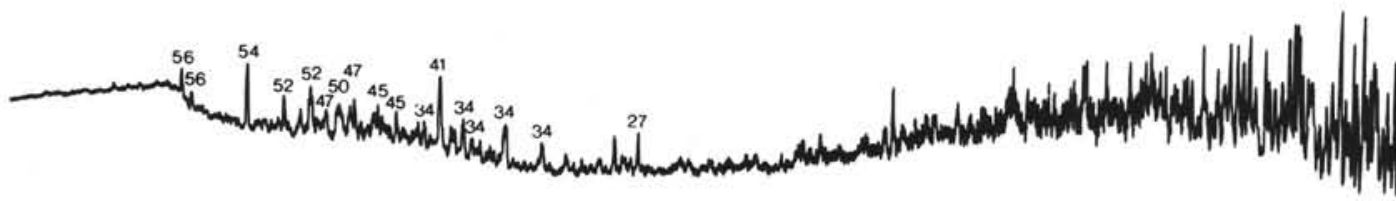

D

Sample 530A-99-5, 0-10 cm $1050.1 \mathrm{~m}$

Cenomanian<smiles>[Tl]</smiles>

${ }_{17}^{16}$

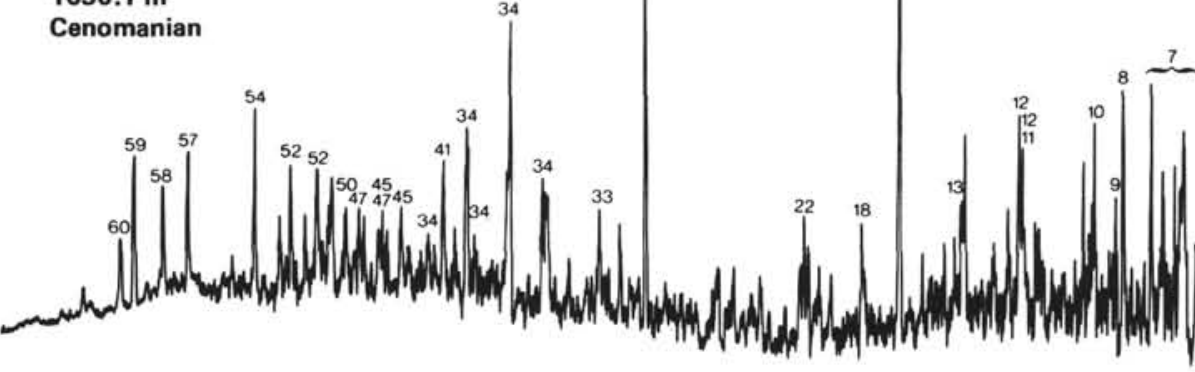

$\leftarrow$ RT

$10 \mathrm{~min}$.

Figure 7. Capillary column gas chromatograms of the aromatic hydrocarbon fractions of selected sediment samples from DSDP Hole 530A (Angola Basin). Numbered compounds are listed in Table 3; $x=$ phthalate ester contaminant. Analytical conditions as for Figure 5 (starting and end temperature slightly variable). (Revisions of stratigraphic ages are given in Steinmetz et al., this volume.) 


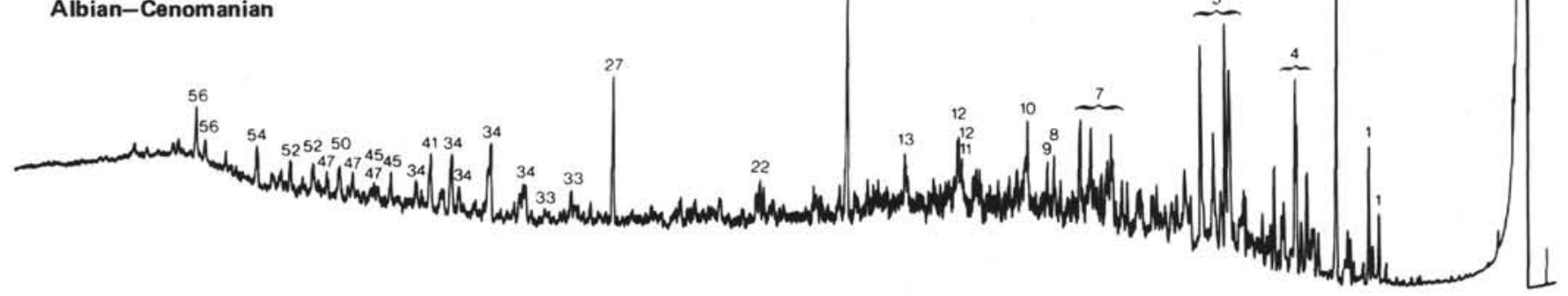

$\mathbf{F}$ Sample 530A-105-1, 90-100 cm $1095.0 \mathrm{~m}$

Albian-Cenomanian
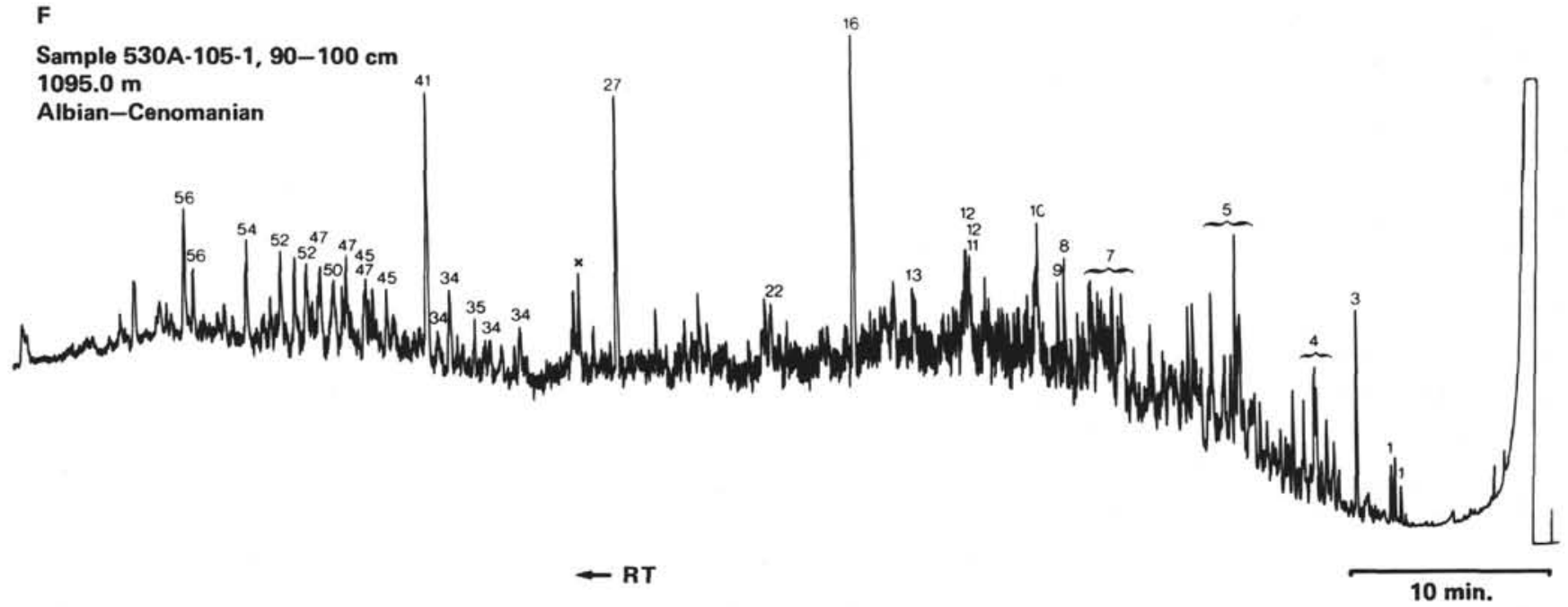

Figure 7. (Continued).

manian green claystone contains more than $60 \%$ inertinite particles (Fig. 2) and only a minor marine organic matter fraction. The nonaromatic hydrocarbons are dominated by higher plant wax $n$-alkanes (Fig. 5E). These data suggest that deposition occurred under oxidizing deep-water conditions as indicated by the deposition of the red claystones as autochthonous pelagic and partly turbiditic background sediment (cf. site summary, this volume).

The overlying black shale, with an organic carbon content one hundred times higher than the green claystone according to shipboard sedimentological observations (site summary, this volume), represents a turbidite deposit. It derived from a zone of oxygen-depleted water where primary deposition occurred under conditions favorable for the preservation of large amounts of organic matter. Flow of debris down slope on steep continental margins, combined with an oxygen-minimum zone in the outer shelf or upper slope area as a result of high bioproductivity, has already been shown to be an important mechanism for the deposition of sediments, rich in organic matter, in the deep sea (Demaison and Moore, 1980; Rullkötter et al., 1983). In the case of the Cenomanian black shale, nearly $80 \%$ of the organic matter appears to be of marine origin. Most of it appears to be affected by microbial reworking, and is thus detected as amorphous bituminite II (Fig. 2). The terrigenous influence, however, is still clearly visible both by kerogen microscopy (Fig. 2) and the $n$-alkane distribution in the nonaromatic hydrocarbon fraction (Fig. 5D) which, as in all other Hole 530A sediments, has a maximum at $n-\mathrm{C}_{31}$ and a strong even-over-odd carbon number predominance. The relatively low hydrogen index from Rock-Eval pyrolysis (Fig. 3) may be an effect of the strong microbial reworking. The high pristane and phytane concentrations in the black shale sample (Fig. 5D) can also be taken as an indication of a depositional environment favorable for the preservation of (marine) organic matter (cf. composition of deep sea sediments from the outer California borderland, Rullkötter et al., 1981; and of a black shale from DSDP Site 367, Rullkötter, Cornford, and Welte, 1982). The dominance of rearranged steroid hydrocarbons, indicating high catalytic activity of the clay matrix (Sieskind et al., 1979), is common in black shales and has also been found in black shales from the North Atlantic (Rullkötter, Cornford, and Welte, 1982) and the Falkland Plateau in the Southeast Atlantic (von der Dick et al., 1983).

The remainder of the Albian/Cenomanian to Coniacian (Core 530A-93) sediments exhibit an intermediate organic facies between the black shale and the green claystone from Section 530A-97-3, some of them even representing sediments of these extremes that could not be separated. The content of macerals of marine origin roughly follows the total amount of organic carbon 


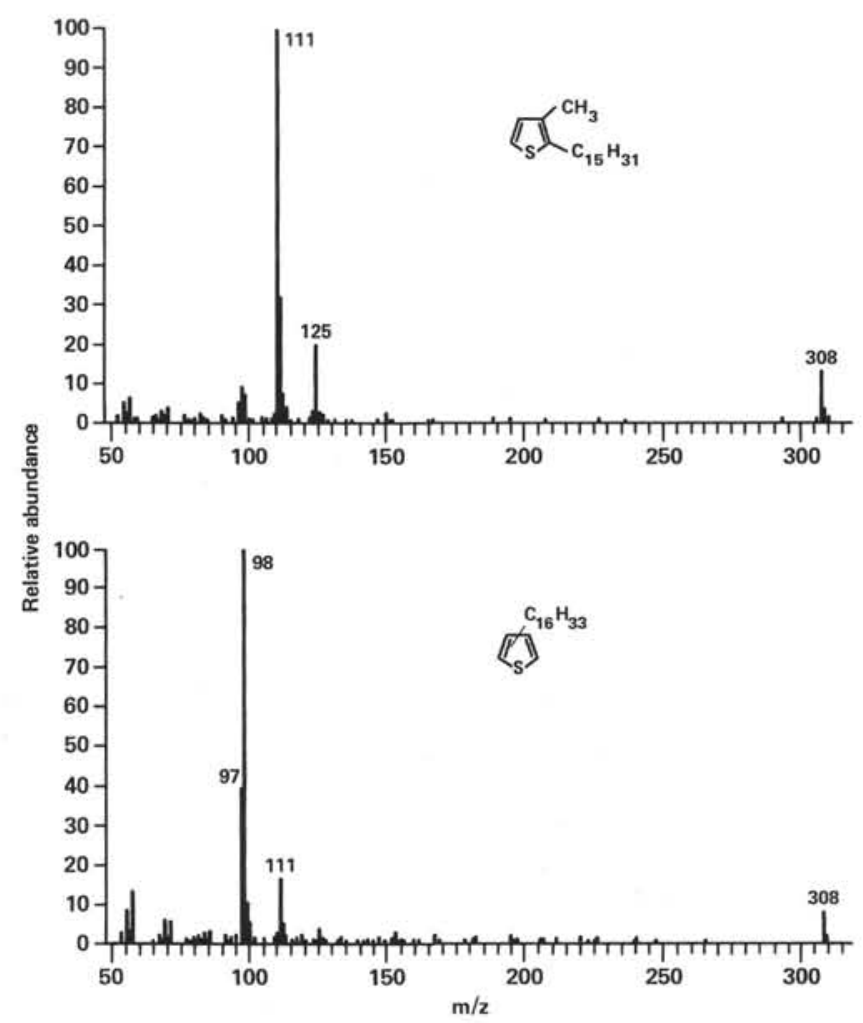

Figure 8. Mass spectra of two isometric $\mathrm{C}_{20}$ alkyl thiophenes. Structures are tentatively derived from mass spectrometric fragmentation only.

present but, except in Section 530A-103-3, terrigenous components dominate (Fig. 2). This indicates an effect of selective mineralization of lipid components, where marine lipids are more easily destroyed or altered than terrigenous lipids. An explanation for this may be better protection of higher plant lipids by their specific cell wall composition or by structural components which are not readily degradable. All nonaromatic hydrocarbon fractions show $n$-alkanes as the most abundant compounds. In contradiction to the microscopic results, Sample 530A-105-1, 90-100 cm has the highest relative concentration of branched and cyclic nonaromatic hydrocarbons rather than Sample 530A-103-3, 110-120 cm (Fig. $5 \mathrm{G}, \mathrm{H}$ ). In the aromatic hydrocarbon fractions of all these sediments, degraded polycyclic terpenoids are abundant components. Among them are nordehydroabietane or an isomer (peak No. 16 in Fig. 7B, E, F), a monoaromatic tetracyclic compound (peak No. 27), and the pentacyclic 7-methyl-3' -ethyl-1, 2-cyclopentanochrysene (peak No. 54). The mass spectrum of the tetracyclic compound fits with the hypothetical structure (27) tentatively assigned to a constituent of the Messel oil shale by Spyckerelle et al. (1977a) and is closely related to the diaromatic octahydrochrysenes found in the Miocene Sample 530A-9-2, 120-137 cm (peak Nos. 28 and 29 , Fig. 7a). The nordehydroabietane may be directly related to a higher plant diterpenoid, or it may be an oxidative degradation product of a 3-oxo triterpenoid like the tetracyclic compounds (Spyckerelle et

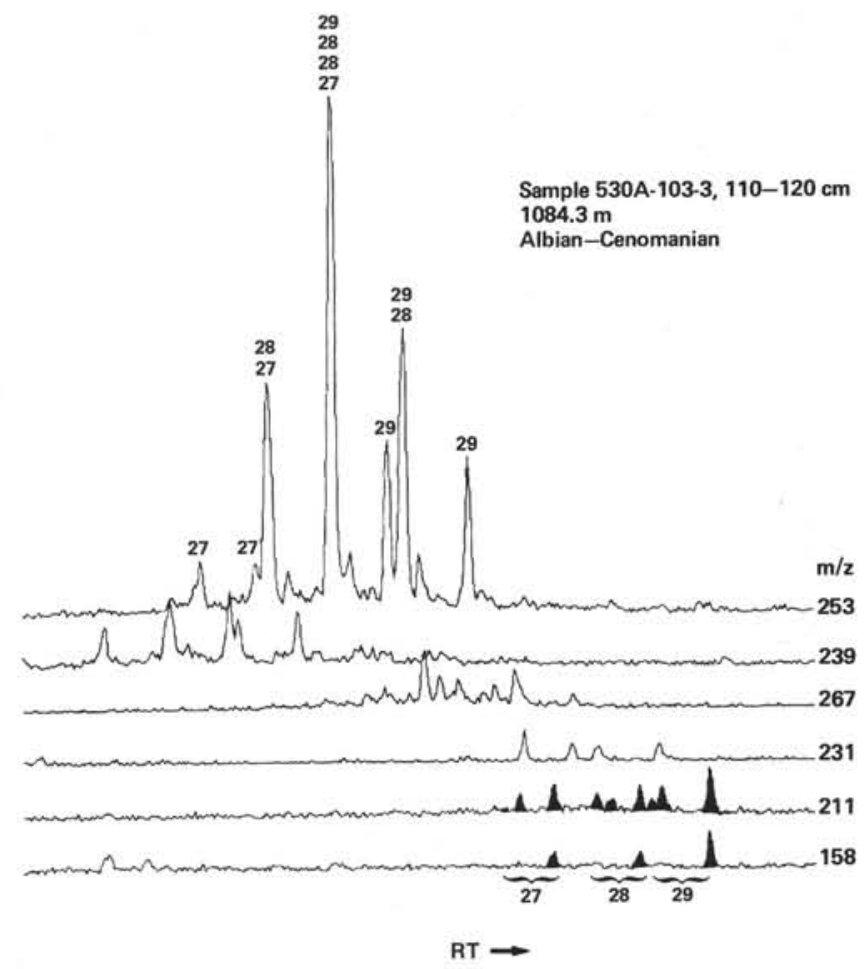

Figure 9. Mass chromatogram of key fragments of aromatic steroid hydrocarbons in the aromatic hydrocarbon fraction of Sample $530 \mathrm{~A}-103-3,110-120 \mathrm{~cm}$ (see text). Numbers indicate carbon numbers of C-ring monoaromatic steroids ( $\mathrm{m} / \mathrm{z} 253$ trace) and A/Bring monoaromatic steroids ( $\mathrm{m} / \mathrm{z} 211$ and 158 traces). (Revisions of stratigraphic ages are given in Steinmetz et al., this volume.)

al., $1977 \mathrm{a}, \mathrm{b}$ ). The cyclopentanochrysene (54) probably is related to the hopane triterpenoids found in the nonaromatic hydrocarbon fractions and indicates bacterial activity (Ourisson et al., 1979).

\section{Diagenesis}

The huminite/vitrinite reflectance measurements show a maturity increase from about $0.3 \% R_{m}$ in the Tertiary samples around $200 \mathrm{~m}$ depth to $0.48 \% R_{m}$ in the Albian-Cenomanian at $1095.0 \mathrm{~m}$ depth. No trend could be established because of the large gap between $200 \mathrm{~m}$ and nearly $1000 \mathrm{~m}$ depth, where measurements were prevented by the low organic carbon concentrations. The same argument affects any detailed discussion of diagenetic alterations in the extractable hydrocarbon fractions. There is a decrease in the odd-over-even carbon number preference (calculated as $2 \mathrm{C}_{31} / \mathrm{C}_{30}+\mathrm{C}_{32}$ ) from the late Miocene sample at $203.8 \mathrm{~m}$ (11.1 for the $\mathrm{C}_{31}$ $n$-alkane) to the Cretaceous sediments, where the CPIvalues range between 6 and 8 for most of the samples, except Sample 530A-97-3, 110-115 cm which has a CPIvalue of 3.7, possibly affected by the high content of reworked organic matter (Fig. 5). The detailed hydrocarbon distributions within the series of Cretaceous samples are apparently more influenced by differences in source organic matter composition than by temperature-related diagenetic alterations over a depth interval of less than $100 \mathrm{~m}$. 


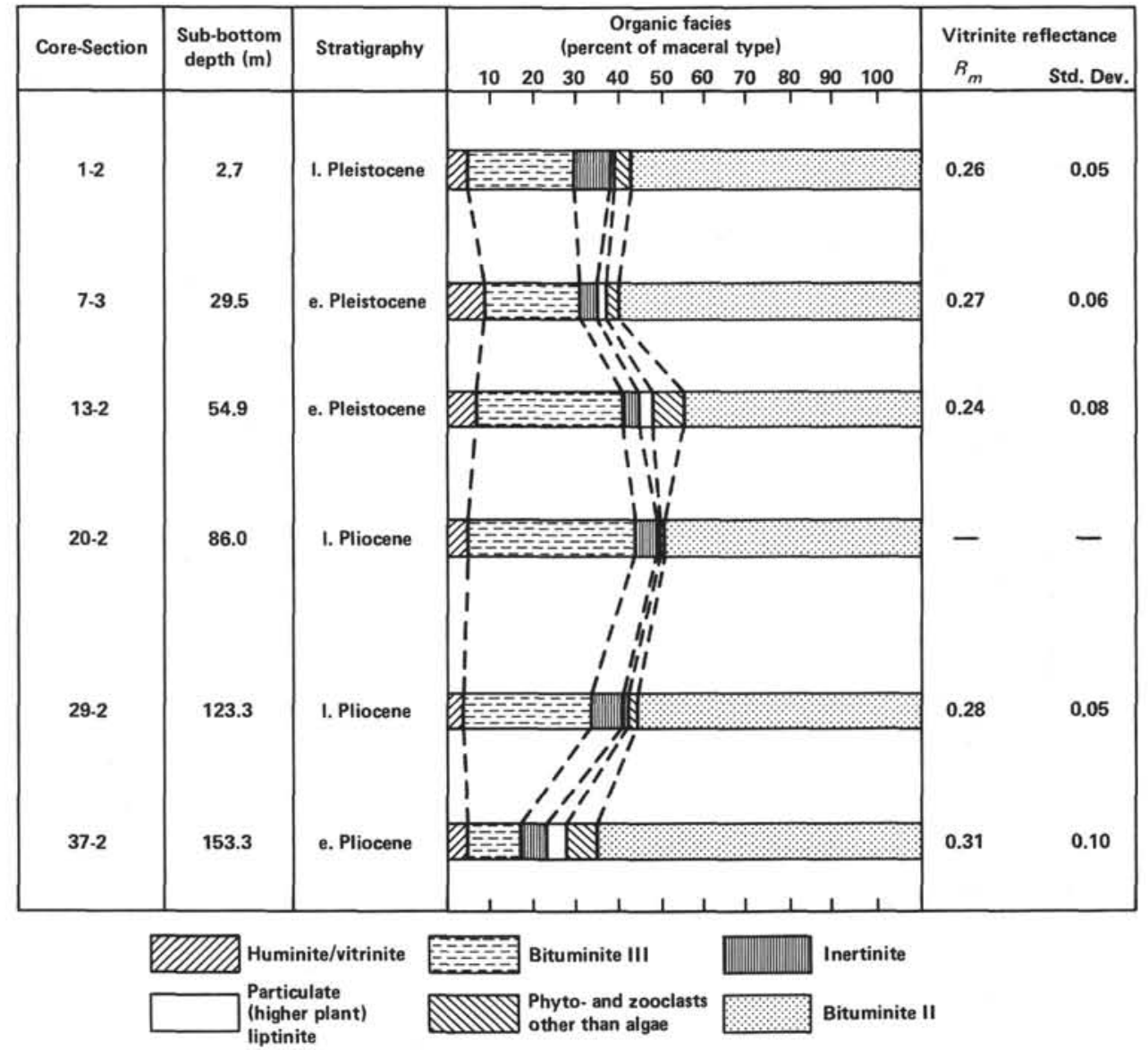

Figure 10. Maceral composition and mean vitrinite reflectance for sediment samples from DSDP Hole 532 (Walvis Ridge).

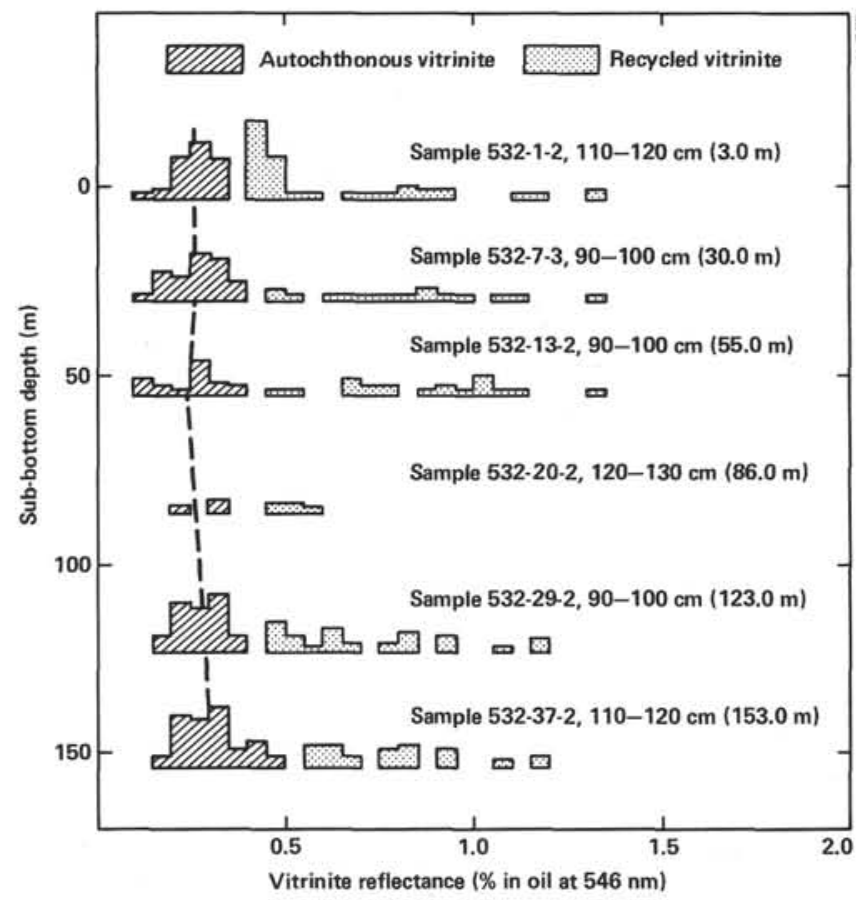

Figure 11. Reflectance histograms of autochthonous (primary) and recycled huminite/vitrinite for sediment samples from DSDP Hole 532 (Walvis Ridge).

\section{DISCUSSION: HOLE 532, WALVIS RIDGE}

The six sediment samples of Pliocene to Pleistocene age from the Walvis Ridge are fairly uniform in maceral (Fig. 10) and nonaromatic hydrocarbon composition (Fig. 12), whereas in the aromatic hydrocarbon fractions analyzed (Fig. 13), the shallowest sample $(2.7 \mathrm{~m}$; late Pleistocene) differs from the other two, probably because of a diagenetic effect. The relatively high organic carbon content in all samples is consistent with a high percentage of marine organic matter, although it is mostly present as amorphous (degraded) bituminite II (Fig. 10). The high amount of organic matter preserved may be related to high primary bioproductivity within the Benguela upwelling regime, but may also be a result of the high sedimentation rates (cf. site summary, this volume). Transport of terrigenous organic matter from the nearby African continent, nonetheless, has been significant over the whole time span. This is indicated both by the maceral analysis (Fig. 10) and the gas chromatograms of the nonaromatic hydrocarbon fractions (Fig. 12) where, partly as a result of the low maturation level, higher plant wax alkanes clearly dominate. The mixed organic matter composition is further supported by the intermediate hydrogen and oxygen index values (Figs. 1 and 3) obtained from the Rock-Eval pyrolysis. 

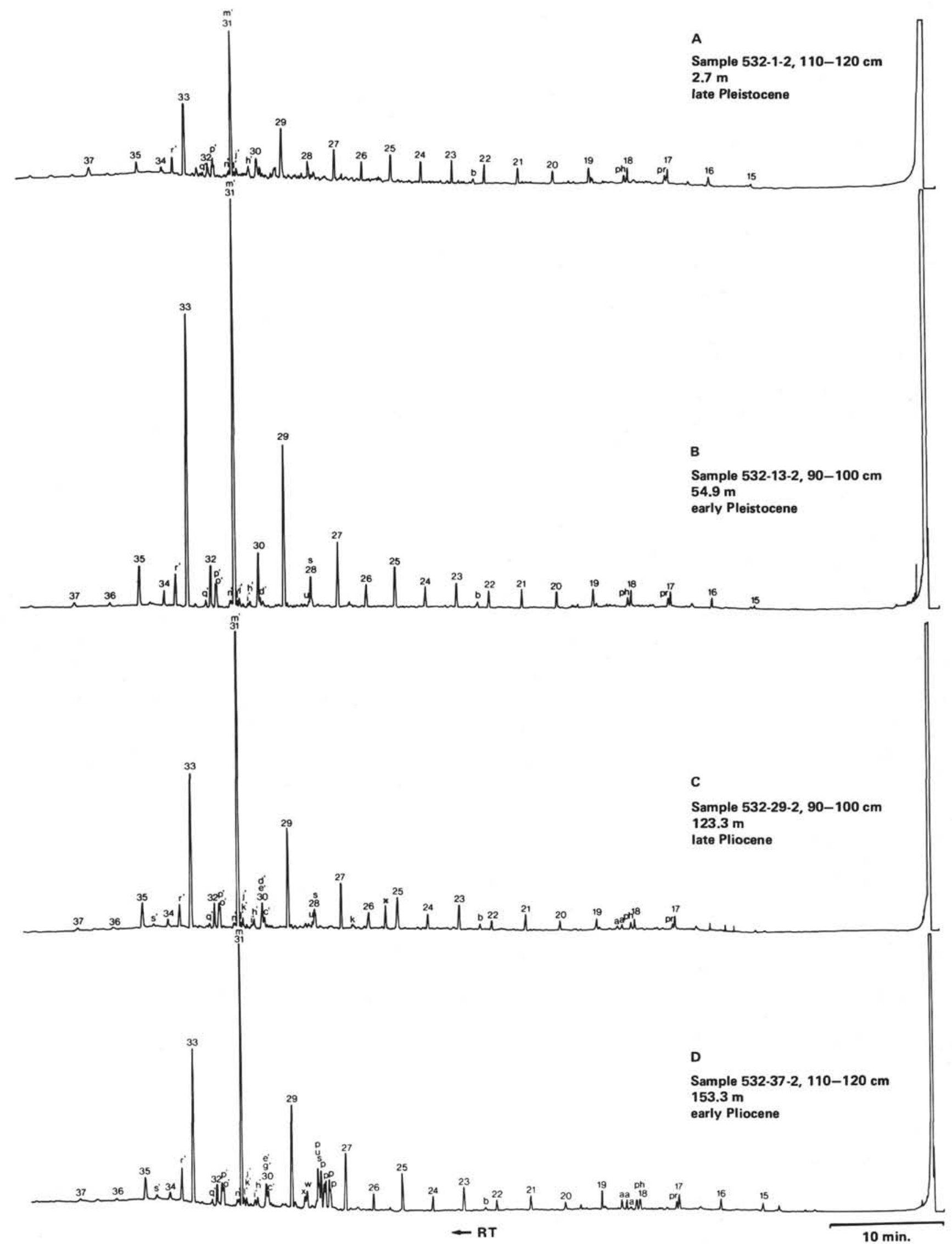

Figure 12. Capillary column gas chromatograms of the nonaromatic hydrocarbon fractions of selected sediment samples from DSDP Hole 532 (Walvis Ridge). Numbers denote $n$-alkanes, lettered compounds are listed in Table 2; pr $=$ pristane, $\mathrm{ph}=\mathrm{phytane}, \mathrm{x}=\mathrm{phthalate}$ ester contaminent. Analytical conditions as for Figure 5. 
A

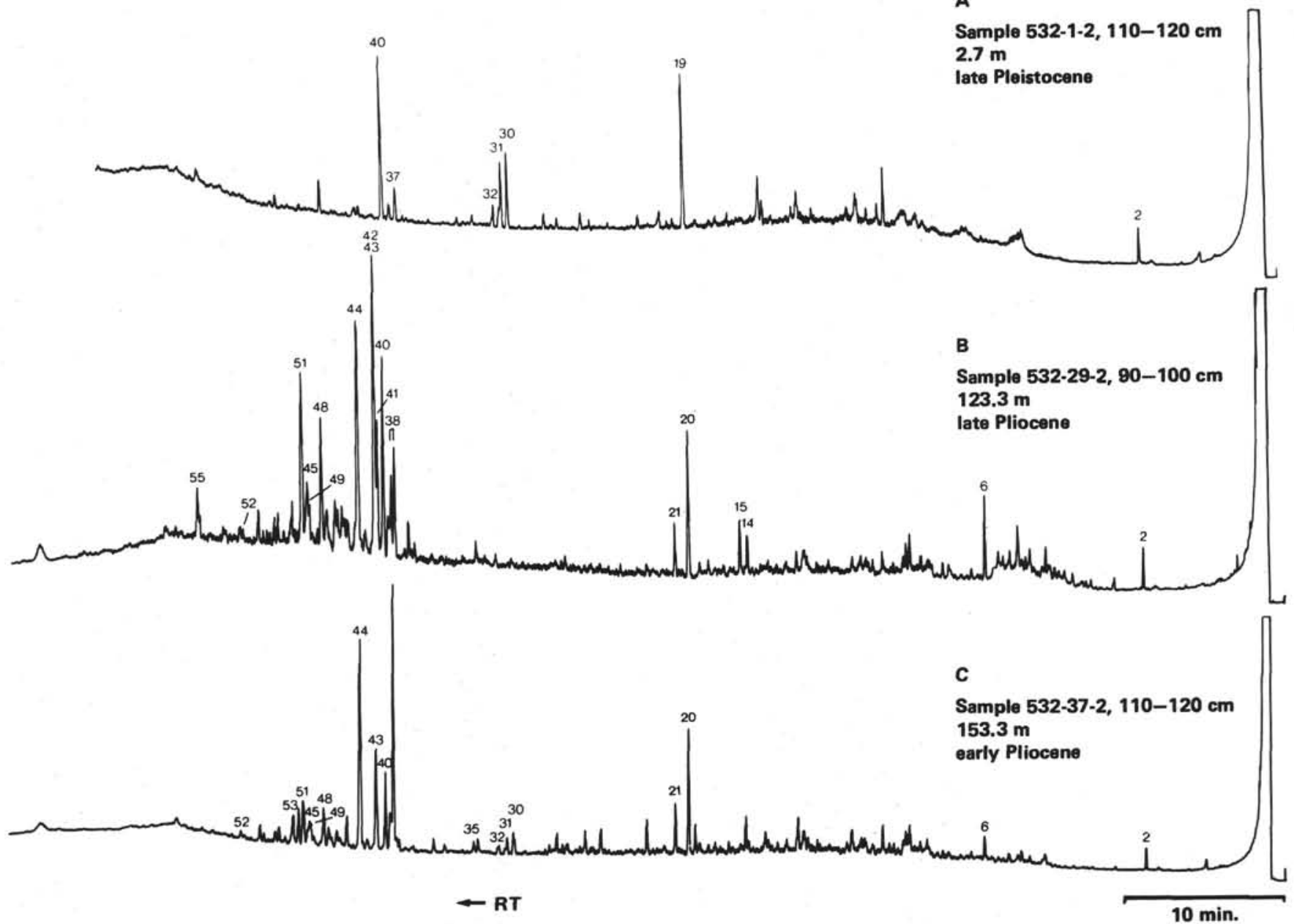

Figure 13. Capillary column gas chromatograms of the aromatic hydrocarbon fractions of selected sediment samples from DSDP Hole 532 (Walvis Ridge). Numbered compounds are listed in Table 3. Analytical conditions as for Figure 5.

\section{CONCLUSIONS}

All sediments from the Angola Basin, DSDP Site 530, and the Walvis Ridge, DSDP Site 532, are strongly influenced by the seaward transport of terrigenous organic matter from the African continent. Under typical deep sea conditions in oxidizing waters, only a small fraction of this material survives, and most is strongly oxidized during transport; virtually all the marine organic matter is destroyed, leading to sediments with usually less than $0.1 \%$ organic carbon. Only down-slope mass transport with, first, high sedimentation and high burial rates and, second, a high content of organic matter in the sediment material from primary deposition in an oxygen-depleted zone leads to deep sea sediments enriched in organic carbon at DSDP Site 530 in the Angola Basin. The amount of marine organic matter preserved usually follows the total organic carbon concentrations. In extreme cases, black shales with more than $10 \%$ organic carbon and a hydrogen-rich Type II kerogen are deposited. At Site 532, Walvis Ridge, the high organic carbon contents, which represent a mixture of terrigenous and marine organic matter, are thought to be related to the high bioproductivity in the Benguela upwelling regime and the high sedimentation rates. Organic matter in all organic-carbon-rich samples investigated seems to be strongly reworked by microbial action as indicated by the dominance of bituminite II and III. The maturation level of the organic matter is low throughout.

\section{ACKNOWLEDGMENTS}

We would like to thank Dr. M. Radke for extraction of the sediments and liquid chromatographic fractionation of the samples, and Dr. J. Gormly for organic carbon and Rock-Eval measurements. Technical assistance by Mrs. B. Kammer, W. Benders, U. Disko, F. Leistner, B. Schmidl, and J. Schnitzler is gratefully acknowledged. We also thank Miss L. Fuckardt for typing the manuscript.

The quality of the chapter benefits from the careful reviews and comments of Dr. W. Giger, EAWAG (Dübendorf, Switzerland) and Dr. J. K. Volkman, Western Australian Institute of Technology (Bentley, Australia). This work was financially supported by the Deutsche Forschungsgemeinschaft (D. F. G., Bonn), Grant No. We 346/25-5.

\section{REFERENCES}

Bolli, H. M., Ryan, W. B. F., and Shipboard Scientific Party, 1978a. Walvis Ridge-Sites 362 and 363. In Bolli H. M., Ryan W. B. F., et al., Init. Repts. DSDP, 40: Washington (U.S. Govt. Printing Office), 183-356.

1978b. Angola continental margin-Sites 364 and 365. In Bolli H. M., Ryan, W. B. F., et al., Init. Repts. DSDP, 40: Washington (U.S. Govt. Printing Office), 357-455. 
Budzikiewicz, H., Djerassi, C., and Williams, D. H., 1967. Mass Spectrometry of Organic Compounds: San Francisco (HoldenDay Inc.), pp. 81-86.

Corbet, B., Albrecht, P., and Ourisson, G., 1980. Photochemical or photomimetic fossil triterpenoids in sediments and petroleum. $J$. Am. Chem. Soc., 102:1171-1173.

Demaison, G. J., and Moore, G. T., 1980. Anoxic environments and oil source bed genesis. Am. Assoc. Petrol. Geol. Bull. 64:1179-1209.

Eglinton, G., and Hamilton, R. J., 1963. The distribution of alkanes. In Swain T. (Ed.), Chemical Plant Taxonomy: London (Academic Press), pp. 187-217.

Espitalié, J., Laporte, J. L., Madec, M., Marquis, F., Leplat, P., Paulet, J., and Boutefeu, A., 1977. Méthode rapide de caractérization des roches-mères, de leur potentiel pétrolier et de leur degre d'evolution. $R$. Inst. Fr. Pet., 32:23-42.

Gormly, J., and Mukhopadhyay, P. K., 1983. Hydrocarbon potential of kerogen types by pyrolysis-gas chromatography. In Bjorøy M. et al. (Eds.), Advances in Organic Geochemistry-1981: Chichester (Wiley).

Hussler, G., Chappe, B., Wehrung, P., and Albrecht, P., 1981. $\mathrm{C}_{27}-\mathrm{C}_{29}$ ring A monoaromatic steroids in Cretaceous black shales. Nature, 294:556-558.

Kinney, I. W., Jr., and Cook, G. L., 1952. Identification of thiophene and benzene homologs. Mass spectral correlations. Anal. Chem., 24:1391-1396.

Mackenzie, A. S., Hoffmann, C. F., and Maxwell, J. R., 1981. Molecular parameters of maturation in the Toarcian shales, Paris Basin, France-III. Changes in aromatic steroid hydrocarbons. Geochim. Cosmochim. Acta, 45:1345-1355.

Mukhopadhyay, P. K., Rullkotter, J., and Welte, D. H., in press. Facies and diagenesis of organic matter in sediments from the Brazil Basin and the Rio Grande Rise, Deep Sea Drilling Project Leg 72. In Barker, P. F., Carlson, R. L., Johnson, D. A. et al., Init. Repts. DSDP, 72: Washington (U.S. Govt. Printing Office).

Ourisson, G., Albrecht, P., and Rohmer, M., 1979. The hopanoids. Paleochemistry and biochemistry of a group of natural products. Pure Appl. Chem., 51:709-729.

Pomonis, J. G., Fatland, C. L., and Zaylskie, R. G., 1976. Mono-, di-, and trisubstituted acyl and alkylthiophenes.-2. Mass spectrometry. J. Chem. Eng. Data, 21:380-385.

Robert, P., 1981. Classification of organic matter by means of fluorescence; application to hydrocarbon source rocks. Int. J. Coal Geol., 1:101-137.

Rullkötter, J., Cornford, C., Flekken, P., and Welte, D. H., 1980. Organic geochemistry of sediments cored during Deep Sea Drilling Project Legs 56 and 57, Japan Trench: Organic petrography and extractable hydrocarbons. In Scientific Party, Init. Repts. DSDP, 56, 57, Pt. 2: Washington (U.S. Printing Office), 1291-1304.

Rullkötter, J., Cornford, C. and Welte, D. H., 1982. Geochemistry and petrography of organic matter in Northwest African continental margin sediments: Quantity, provenance, depositional environment and temperature history. In Von Rad, U., Hinz, K., Sarnthein, M., and Seibold, E. (Eds.), Geology of the Northwest African Continental Margin: Berlin, Heidelberg, New York (SpringerVerlag), pp. 686-703.
Rullkötter, J., von der Dick, H., and Welte, D. H., 1981. Organic petrography and extractable hydrocarbons of sediments from the eastern North Pacific Ocean, Deep Sea Drilling Project Leg 63. In Yeats, R. S., Haq, B. U., et al., Init. Repts. DSDP, 63: Washington (U.S. Govt. Printing Office), 819-836.

1982. Organic petrography and extractable hydrocarbons of sediments from the Gulf of California, Deep Sea Drilling Project Leg 64, In Curray, J. R., Moore, D. G., et al., Init. Repts. DSDP, 64, Pt. 2: Washington (U.S. Govt. Printing Office), 819-836.

Rullkötter, J., Vuchev, V., Hinz, K., Winterer, E. L., et al., 1983. Potential deep-sea petroleum source beds related to coastal upwelling. In Suess, E., and Thiede, J. (Ed.), Coastal Upwelling: Its Sediment Record, Pt. 2. Sedimentary Records of Ancient Coastal Upwelling: New York (Plenum), pp. 467-484.

Rullkötter, J., and Welte, D. H., in press. Maturation of organic matter in areas of high heat flow: A study of sediments from DSDP Leg 63, offshore California, and Leg 64, Gulf of California. In Bjoroy, M., et al. (Ed.), Advances in Organic Geochemistry1981: Chichester (Wiley).

Sieskind, O., Joly, G., and Albrecht, P., 1979. Simulation of the geochemical transformation of sterols: Superacid effect of clay minerals. Geochim. Cosmochim. Acta, 43:1675-1679.

Spyckerelle, C., Greiner, A.Ch., Albrecht P., et al., 1977a. Aromatic hydrocarbons from geological sources, Part III. A tetrahydrochrysene derived from triterpenes, in recent and old sediments: 3,3,7-trimethyl-1,1,3,4-tetrahydrochrysene. J. Chem. Res. (M) 1: 3746-3754.

1977b. Aromatic hydrocarbons from geological sources, Part IV. An octahydrochrysene derived from triterpenes, in oil shales: 3,3,7,12a-tetramethyl-1,2,3,4,4a,11,12,12a-octahydrochrysene. J. Chem. Res. (M), 1:3801-3805.

Stach, E., Mackowsky, M. T., Teichmüller, M., Taylor, G. H., Chandra, D., and Teichmüller, R., 1975. Coal Petrology: Berlin, Stuttgart (Gebruder Bornträger), p. 428.

Teichmüller, M., and Ottenjann, K., 1977. Art und Diagenese von Liptiniten und lipoiden Stoffen in einem Erdölmuttergestein auf Grund fluoreszenzmikroskopischer Untersuchungen. Erdöl Kohle Petrochem., 30:387-398.

Tissot, B. P., and Welte, D. H., 1978. Petroleum Formation and Occurrence: A New Approach to Oil and Gas Exploration: Berlin, Heidelberg, New York (Springer-Verlag).

van Gijzel, P., 1981. Applications of geomicrophotometry of kerogen, solid hydrocarbons and crude oils to petroleum exploration. In Brooks, J. (Ed.), Organic Maturation and Fossil Fuel Exploration: New York (Academic Press), pp. 351-377.

von der Dick, H., Rullkötter, J., and Welte, D. H., 1983. Content, type and thermal evolution of organic matter in sediments from the eastern Falkland Plateau, Deep Sea Drilling Project Leg 71. In Krasheninnikov, V., Ludwig, W., et al., Init. Repts. DSDP, 71: Washington (U.S. Govt. Printing Office), 1015-1032.

Welte, D. H., Cornford, C., and Rullkötter, J., 1979. Hydrocarbon source rocks in deep sea sediments. Proc. 11th Annual Offshore Technology Conf. (Houston), 1:457-464.

Date of Initial Receipt: October 15, 1982 
Table 4. Aromatic hydrocarbons, identified or characterized by major peaks in their mass spectra, occuring in sediments from DSDP Holes 530A and 532 (cf. Figs. 7 and 13).

\begin{tabular}{|c|c|c|c|}
\hline No. & Compound & $\mathbf{M}^{+}$ & $\begin{array}{l}\text { Major mass spectral peaks } \\
\text { (rel. intensity, \%) }\end{array}$ \\
\hline 1 & Methylnaphthalenes & 142 & \\
\hline 2 & Cyclohexylcyclohexane (contaminant?) & 166 & $166(15), 83(50), 82(100)$ \\
\hline 3 & lonene (1,1,6-trimethyl-1,2,3,4-tetrahydronaphthalene)? & 174 & $174(18), 159(100)$ \\
\hline 4 & $\mathrm{C}_{2}$-naphthalenes & 156 & \\
\hline 5 & $\mathrm{C}_{3}$-napthalenes & 170 & \\
\hline 6 & 2-methylbiphenyl & 168 & $168(100), 167(50), 165(50), 153(60)$ \\
\hline 7 & $\mathrm{C}_{4}$-napthalenes & 184 & \\
\hline 8 & Phenanthrene & 178 & \\
\hline 9 & Alkylbenzene & 246 & $246(15), 106(100), 105(60)$ \\
\hline 10 & Alkylbenzene & 246 & $246(10), 120(54), 119(100)$ \\
\hline 11 & Alkylbenzene & $274(?)$ & $119(100)$ \\
\hline 12 & Methylphenthrenes & 192 & \\
\hline 13 & Unknown & 256 & $256(20), 241(100)$ \\
\hline 14 & Unknown & 208 & $208(100), 207(30), 180(17), 179(20), 165(23)$ \\
\hline 15 & Unknown & 208 & $208(100), 207(32), 193(10), 179(14), 178(13), 165(29)$ \\
\hline 16 & Nordehydroabietane? & 256 & $256(35), 241(75), 171(63), 159(68), 145(100), 69(34)$ \\
\hline 17 & Pyrene & 202 & \\
\hline 18 & Alkylbenzene & $?$ & $106(100), 105(60)$ \\
\hline 19 & Unknown & 219 & $291(100), 218(48), 271(48), 108.5(18)$ \\
\hline 20 & Alkylthiophene & 308 & cf. Fig. $8 \mathrm{a}$ \\
\hline 21 & Alkylthiophene & 308 & cf. Fig. $8 \mathrm{~b}$ \\
\hline 22 & Alkylbenzene & 316 & $316(15), 106(100), 105(70)$ \\
\hline 23 & Unknown & 216 & $216(100), 215(53)$ \\
\hline 24 & Alkylbenzene & 316 & $316(15), 120(75), 119(100)$ \\
\hline 25 & Alkylbenzene & 330 & $330(15), 120(100), 119(75)$ \\
\hline 26 & Unknown & 326 & $326(5), 311(30), 108(100), 95(90)$ \\
\hline 27 & Pentamethyldodecahydrochrysene? & 310 & $310(20), 295(70), 171(50), 157(100), 137(80)$ \\
\hline 28 & $\begin{array}{l}3,3,7,12 \mathrm{a} \text {-tetramethyl-1, } 2,3,4,4 \mathrm{a}, 11,12,12 \mathrm{a}- \\
\text { octahydrochrysene }\end{array}$ & 292 & $292(100), 207(20), 193(15), 181(12), 168(17)$ \\
\hline 29 & $\begin{array}{l}\text { Isomer of } 29(3,4,7,12 \mathrm{a} \text {-tetramethyl- } \\
\qquad 1,2,3,4,4 \mathrm{a}, 11,12,12 \mathrm{a} \text {-octahydrochrysene? })\end{array}$ & 292 & 292(100), 209(47), 207(95), 193(15), 168(30) \\
\hline 30 & Unknown & 207 & $207(84), 206(21), 129(60), 105(22), 91(100)$ \\
\hline 31 & Unknown & 207 & $207(86), 206(22), 129(62), 105(18), 91(100)$ \\
\hline 32 & Unknown & 207 & $207(93), 206(18), 129(58), 105(15), 91(100)$ \\
\hline 33 & C-ring aromatic steroid (BP 239) & - & $239(100)$ \\
\hline 34 & C-ring aromatic steroid (BP 253) & - & $253(100)$ \\
\hline 35 & 3,3,7-trimethyl-1,2,3,4-tetrahydrochrysene & 274 & $274(60), 218(100)$ \\
\hline 36 & Unknown & 400 & $400(20), 175(23), 135(100)$ \\
\hline 37 & Unknown & 410 & $\begin{array}{l}410(4), 395(7), 177(16), 176(15), 149(27), 123(35) \\
109(42), 81(100)\end{array}$ \\
\hline 38 & Sterene ? $\left(\mathrm{C}_{27}\right)$ & 370 & \\
\hline 39 & Unknown & 410 & $410(2), 341(3), 137(18), 95(21), 81(58), 69(100)$ \\
\hline 40 & Alkylthiophene & 378 & $378(25), 111(25), 98(52), 97(100)$ \\
\hline 41 & Unknown & 414 & $414(20), 189(100), 149(100)$ \\
\hline 42 & Steradiene? $\left(\mathrm{C}_{27}\right)$ & 368 & $368(100)$ \\
\hline 43 & Perylene & 252 & $252(100)$ \\
\hline 44 & Steratriene ? $\left(\mathrm{C}_{28}\right)$ & 380 & $380(80), 255(65), 105(63), 81(95), 69(95), 55(100)$ \\
\hline 45 & Ring A/B-monaromatic steroid $\left(C_{27}\right)$ & 366 & \\
\hline 46 & Steratetraene ? $\left(\mathrm{C}_{28}\right)$ & 378 & $378(28), 253(100), 199(35)$ \\
\hline 47 & Ring A/B-monoaromatic steroid $\left(\mathrm{C}_{28}\right)$ & 380 & \\
\hline 48 & Steratriene ? $\left(\mathrm{C}_{29}\right)$ & 394 & $394(68), 255(50), 145(48), 81(100)$ \\
\hline 49 & Alkylthiophene & 406 & $406(48), 98(60), 97(100)$ \\
\hline 50 & Steratetraene ? $\left(\mathrm{C}_{29}\right)$ & 392 & $293(50), 349(100), 235(48), 211(43)$ \\
\hline 51 & Unknown & 396 & $396(13), 381(5), 231(100)$ \\
\hline 52 & Ring A/B-monoaromatic steroid $\left(\mathrm{C}_{29}\right)$ & 394 & \\
\hline 53 & Unknown & 378 & $378(100), 253(50), 211(70), 159(45)$ \\
\hline 54 & 7-methyl-3'-ethyl-1,2-cyclopentenochrysene & 310 & $310(50), 281(100), 266(25), 265(30)$ \\
\hline 55 & Unknown & 428 & $428(40), 245(100)$ \\
\hline 56 & Unknown & 444 & $444(60), 197(50), 169(100)$ \\
\hline 57 & Unknown & 418 & $418(25), 403(85), 197(100), 158(55)$ \\
\hline 58 & Unknown & 432 & $432(20), 226(40), 211(58), 191(100), 157(45)$ \\
\hline 59 & Unknown & 446 & $\begin{array}{l}446(30), 431(10), 240(50), 226(50), 191(100) \text {. } \\
158(65)\end{array}$ \\
\hline 60 & Unknown & 300 & $300(100), 150(20)$ \\
\hline
\end{tabular}


<smiles>CC(C)CCCC(C)CCCC(C)CCCCC(C)CCCC(C)CCCC(C)C</smiles>

squalane (k ?)<smiles>[R]C(CCC(C)C1CCC2C1CCC13CCCCC1=C(C)CCC23)C(C)C</smiles>

ster-5-enes

$\mathrm{R}=\mathrm{H}(\underline{u}), \mathrm{CH}_{3}, \mathrm{C}_{2} \mathrm{H}_{5}\left(\underline{e^{\prime}}\right)$

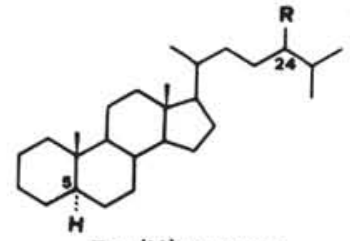

$5 a(\mathrm{H})$-steranes $\mathrm{R}=\mathrm{H}(\underline{v}), \mathrm{CH}_{3}, \mathrm{C}_{2} \mathrm{H}_{5}\left(\underline{f^{\prime}}\right)$<smiles>[R]C(CCC(C)C1=C2CCC3C4CCCCC4(C)CCC3C2(C)CC1)C(C)C</smiles>

$\mathrm{R}=\mathrm{H}, \mathrm{CH}_{3}, \mathrm{C}_{2} \mathrm{H}_{5}$<smiles>CC(C)C(C)C=CC(C)C1CCC2C1CCC1C3CCCC=C3CCC12</smiles>

24-methylcholesta4, 22-diene ( $\underline{w})$

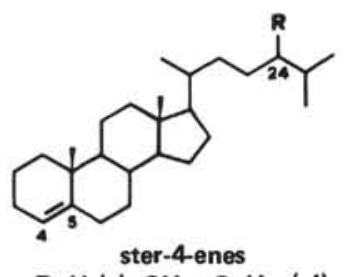

$\mathrm{R}=\mathrm{H}(\underline{\mathrm{s}}), \mathrm{CH}_{3}, \mathrm{C}_{2} \mathrm{H}_{5}\left(\underline{\left.\mathrm{c}^{\prime}\right)}\right.$

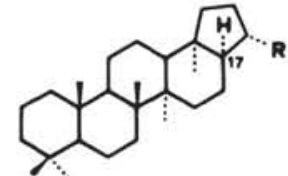

$17 a(\mathrm{H})$-hopanes $\mathrm{R}=\mathrm{H}(\underline{\mathrm{y}}), \mathrm{C}_{2} \mathrm{H}_{5}\left(\mathrm{~d}^{\prime}\right), \mathrm{CH}\left(\mathrm{CH}_{3}\right)_{2} \underline{\left(\mathrm{j}^{\prime}\right)}$

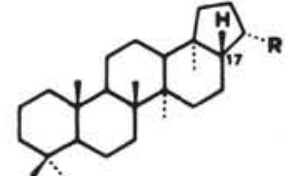

$17 \beta$ (H)-hopanes $\mathrm{R}=\mathrm{H}(\underline{z}), \mathrm{C}_{2} \mathrm{H}_{5}\left(\mathrm{~m}^{\prime}\right), \mathrm{CH}\left(\mathrm{CH}_{3}\right)_{2}\left(\mathrm{~g}^{\prime}\right)$, $\mathrm{CH}\left(\mathrm{CH}_{3}\right) \mathrm{C}_{2} \mathrm{H}_{5}\left(\underline{r}^{\prime}\right), \mathrm{CH}\left(\mathrm{CH}_{3}\right) \mathrm{C}_{3} \mathrm{H}_{7}\left(\underline{s}^{\prime}\right.$<smiles>[R]C(C)C1CCC2=C3CCC4C(CCC5C(C)(C)CCCC45C)C3CCC21</smiles>

hop-13 (18)-enes $\mathrm{R}=\mathrm{H}\left(\underline{b}^{\prime}\right), \mathrm{CH}_{3}\left(\underline{(k}^{\prime}\right)$<smiles>[R]C(C)C1=C2CCC3C(CCC4C3CCC3C4CCCC3(C)C)C2CC1</smiles>

hop-17 (21)-enes $\mathrm{R}=\mathrm{H}\left(\underline{g}^{\prime}\right), \mathrm{Ch}_{3}\left(\underline{\left.h^{\prime}\right)}\right.$

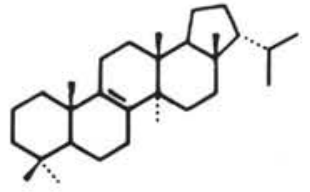

fern-8-ene $\left(\underline{k}^{\prime}\right)$<smiles>CCCCCCC1=C2CCCCC2C2CCC3C(C(C)CCC(C)C(C)C)CCC3C2C1</smiles><smiles>CCC(C)C1CCC2C1CCC1C3CCC(CC)C3CCC21</smiles>

30-normoretane (i')<smiles>CC(C)[C@H]1CCC2C1CCC1C3CCC4C(C)(C)CCC[C@]4(C)C3=CCC12C</smiles>

fern-9 (11)-ene $\left(n^{\prime}\right)$<smiles>CC(C)c1ccc2c(c1)CCC1C(C)CCC[C@@]21C</smiles>

phenanthrene $(\underline{8})$<smiles>c1ccc2c(c1)ccc1ccccc12</smiles>

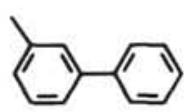

2-methylbiphenyl (ㅁ) ionene (3)<smiles>Cc1ccc2c(c1)CCCC2(C)C</smiles>

fern-7-ene $\left(p^{\prime}\right)$<smiles>Cc1cccc2c1CCC1C2CCC2(C)CCC(C)CC12</smiles>

27?<smiles>Cc1cccc2c3c(ccc12)C1CC(C)(C)CCC1(C)CC3</smiles>

$\underline{28}$<smiles>Cc1cccc2c3c(ccc12)C1C(C)CCCC1(C)CC3</smiles>

$\underline{29}$ ?<smiles>Cc1cccc2c1ccc1c3c(ccc12)CCC(C)C3</smiles>

35<smiles>c1cc2cccc3c4cccc5ccc6cccc(c(c1)c23)c4c65</smiles>

43<smiles>[R]C(CCC(C)(C)[C@]1(C)CCc2c1ccc1c2CC[C@H]2CCCC[C@]12C)C(C)C</smiles>

C-ring monoarom. steroids $\mathrm{R}=\mathrm{H}, \mathrm{CH}_{3}, \mathrm{C}_{2} \mathrm{H}_{5}$<smiles>[R]C(CCC(C)C1CCC2C3CCc4c(cccc4C3C)CCC12)C(C)C</smiles>

A-ring monoarom. steroids $\mathrm{R}=\mathrm{H}, \mathrm{CH}_{3}, \mathrm{C}_{2} \mathrm{H}_{5}$<smiles>[R]C(CCC(C)C1CCC2C3c4c(C)cc5c(c4CCC3C12C)CCCC5)C(C)C</smiles>
$\mathrm{R}=\mathrm{H}, \mathrm{CH}_{3}, \mathrm{C}_{2} \mathrm{H}_{5}$<smiles>CC[C@H]1CCc2c1ccc1c3ccc4c(C)cccc4c2ccc13</smiles>

54 

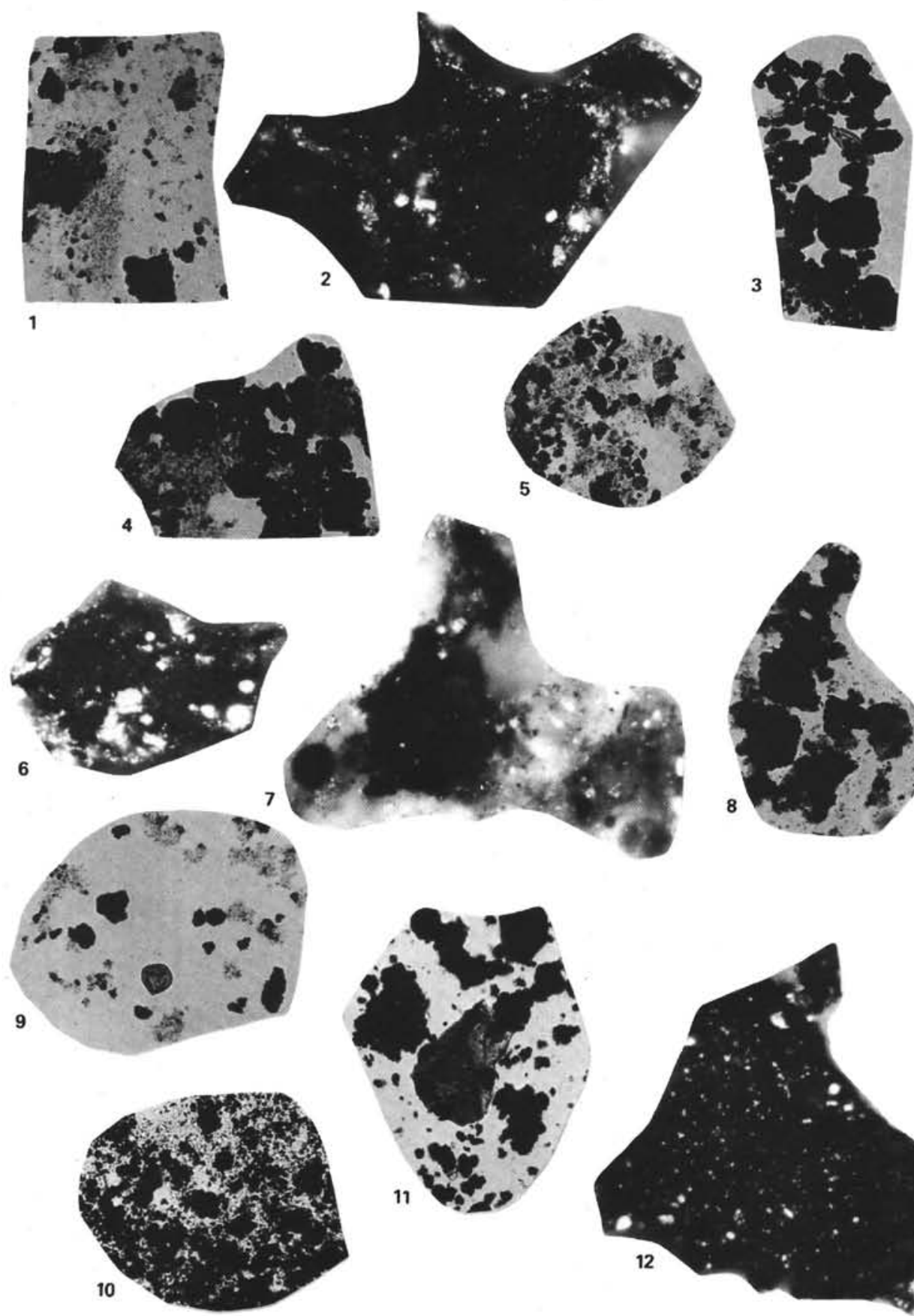

.
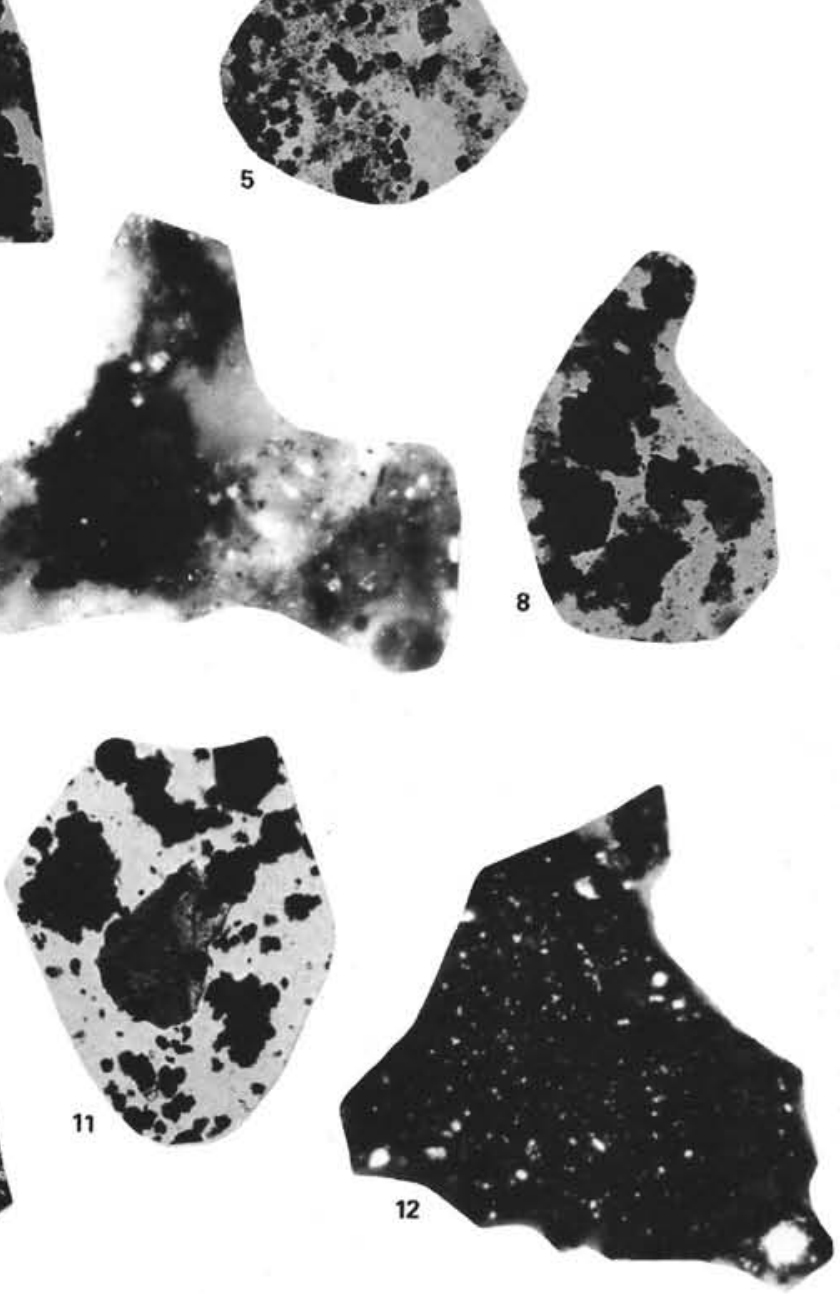

Plate 1. Petrography of organic matter, Leg 75 (Figs. 1, 3-5, and 8-11, transmitted light, $\times 160 ;$ Figs. 2, 6, 7, 12, normal reflected light, $\times 400$ ). 1. Amorphous liptinite, dinoflagellate, humic matter; Sample $530 \mathrm{~A}-97-3,105-110 \mathrm{~cm}$. 2. Bituminite II and framboidal pyrite; Sample $530 \mathrm{~A}-97-3,105-110 \mathrm{~cm}$. 3. Amorphous humic matter and pollen; Sample 530A-93-5, 135-145 cm. 4. Mixture of amorphous humic and liptinite matter; Sample 530A-97-3, 105-110 cm. 5. Mixed palynofacies: dinoflagellate, amorphous liptinitic and humic (dark) matter; Sample $530 \mathrm{~A}-97-3,105-110 \mathrm{~cm}$. 6. Bituminite III with framboidal pyrite; Sample 530A-103-3, 110-120 cm; separated kerogen. 7. Bituminite II and III in mineral matrix (may be degraded dinoflagellates? and spores) with framboidal pyrite; whole rock block; Sample 530A-103-3, 110-120 cm. 8. Mixed organic facies. Dinoflagellates(?) and amorphous humic matter; Sample 530A-105-1, 90-100 cm. 9. Mixed organic facies. Amorphous humic and liptinitic matter with spore; Sample 530A-105-1, 90-100 cm. 10. Amorphous humic and liptinitic matter; Sample 532-20-2, $120-130 \mathrm{~cm}$. 11. Mixed organic facies with zooclasts(?) and amorphous humic matter; Sample 532-7-3,90-100 cm. 12. Bituminite II with framboidal pyrite; Sample 532-37-2, 110-120 cm. 